\title{
JAV didžiosios strategijos kaita ir jos pasekmès Lietuvai
}

\begin{abstract}
Po NATO ir Europos Sajungos pletros Lietuva susiduria su nauju iššūkiu: nustatyti naujus užsienio ir saugumo politikos tikslus, peržiūrèti senus prioritetus, juos pritaikyti prie naujų geostrateginės aplinkos realijų. Santykiai su JAV, kaip pačia stipriausia pasaulio valstybe, taip pat turi pereiti į naują etapą. Tai diktuoja tiek Europoje, tiek Amerikoje besikeičiantis pasaulio bei iš jo kylančiu grèsmių supratimas. Pastarasis aspektas - kaip, žiūrint iš Vašingtono, atrodo Lietuvos vaidmuo Europoje ir pasaulyje, kaip Lietuva gali prisideti prie JAV užsienio politikos tikslų igyvendinimo ir kokie bendri iššñkiai laukia abiejų valstybių pagrindinis šio straipsnio akcentas.
\end{abstract}

XX amžius pasaulio istorijoje bus žinomas kaip Amerikos hegemonijos ir dominavimo amžius. Pasaulio žemėlapis tiek Europoje, tiek Azijoje, tiek Afrikoje per šimtmetị nusidažè kitomis spalvomis, ir tik vienintelis Amerikos žemynas išvengè revoliuciniu permainų, o galingiausia jos valstybè - JAV - tapo šio stabilumo garantu. Per pastarajį šimtmetį Amerikos strategija išoriškai mažai pasikeite -joje darniai susipynė senosios tradicijos ir naujos idejos.

Rugsèjo $11 \mathrm{~d}$. teroristiniai išpuoliai pridejo naują matmenį prie šimtmečiais besiformavusio grèsmių supratimo. Pirmą kartą JAV buvo atakuota jos pačios teritorijoje, o asimetrinis atsakas tapo JAV strategijos pagrindiniu elementu. Pirmą kartą po Šaltojo karo pabaigos susiformavo ryškus priešo įvaizdis, aiškiai įvardinta nauja grèsmè ir skirti didžiuliai resursai su ja kovoti. Pasikeitus JAV interesų supratimui, strateginėms koncepcijoms bei grèsmių analizei pakito JAV požiūris ị tam tikrus regionus ir valstybes, partnerius ir priešus ${ }^{1}$.

Lietuva tiesiogiai patiria besikeičiančio JAV grèsmių ir nacionalinių interesų supratimo pokyčius - karinè pagalba, NATO plètra, sustiprèjo politiniai kontaktai visa tai simbolizuoja JAV politikos Lietuvos atžvilgiu kaitą. Šie pokyčiai - dvipusio proceso pasekmè. Visu pirma pasikeitė JAV pasaulio supratimas ir požiūris ị Europos valstybių vaidmenį JAV globalinëje strategijoje. Europa neberra konflikto zona kaip buvo Šaltojo karo metais. Pagrindinès grèsmès JAV saugumui slypi kitose pasaulio dalyse, į kurias ir nukreiptas pagrindinis JAV užsienio politikos dėmesys.

\footnotetext{
"Vaidotas Urbelis - Vilniaus universiteto Tarptautinių santykių ir politikos mokslų instituto dèstytojas. Adresas: Vokiečių 10, 2001 Vilnius, tel. 8-698-11348, e-paštas: vaidotas@post.omnitel.net ${ }^{1}$ Zr. The National Security Strategy of the United States of America. September 2002.
} 
Antra, Lietuvos ir kitų regiono valstybių politiniai, ekonominiai ir kultūriniai laimèjimai didina Amerikos susidomėjimą regionu. JAV reikalingi sajungininkai siekiant išlaikyti dominavimą Europoje ir pasaulyje bei kovoti prieš naujo tipo grèsmes kaip terorizmas.

Pokyčiai JAV globalinëje strategijoje kelia daugybę svarbių klausimų tiek akademinei visuomenei, tiek sprendimų prièmėjams daugelyje pasaulio šalių: koks bus JAV vaidmuo Europoje ateityje, kokị vaidmenį JAV skirs Lietuvai ir kitoms regiono valstybėmis, kokių priemonių Lietuva turi imtis, siekdama užtikrinti amerikiečiu paramą, siekiant savo geostrateginių tikslų.

Siame darbe pirmiausia bus siekiama nustatyti, kokie yra globalūs JAV užsienio politikos interesai ir kokią vietą jų iggvendinimo strategijoje užima Lietuva, Baltijos valstybės bei regionai, kuriems jos priklauso. Lietuva ir kitos šalys geostrateginiu požiūriu priklauso dviems regionams, visų pirma Siaurés Europos regionui, kuris vienija šiaurinę išplèstos Europos Sajungos dali. Tuo pačiu kartu su kitomis V 10 šalimis mus vienija tas pats noras užsitikrinti savo saugumą tampant NATO dalimi ir gaunant JAV saugumo garantijas. Šioms šalims apibūdinti prigijo Vidurio ir Rytų (VR) Europos regiono sąvoka. Po narystès NATO ši bendra identifikacija greičiausiai po truputị nyks, užleisdama vietą šiaurietiškajam identitetui.

Center for Strategic and International Studies (CSIS) ir Tarptautinių santykių ir politikos mokslų instituto (TSPMI) rengtoje Lietuvos užsienio politikos Baltojoje knygoje naudojamas kitas terminas - Baltijos-Vidurio Rytų Europos regionas. Autoriai tvirtina, kad „Vidurio Europos ir Baltijos regionai persidengia tiek istorinès patirties, tiek kontinentinio identiteto, kultūrinio savitumo, politinès evoliucijos ir ekonominės plètros prasme“2 . Baltijos-Vidurio Rytų Europos regiono sąvoka faktiškai sutampa su VR ir Šiaurès Europos sąvoka, išskyrus, kad pastaroji neapima šiaurès vakarinès Rusijos dalies. Dèl skirtingos Rusijos šiaurès vakarinès dalies ir kitų regiono valstybių geostrateginių orientacijų, šiame darbe bus naudojama VR ir Šiaurès Europos sąvoka.

Lietuvos geopolitinè orientacija turi daugybę bendrų bruožų tiek su Šiaurès Europos, tiek su VR Europos valstybių vykdoma politika. Lietuvos analizé, kai ją suvokiame kaip dviejų regionų valstybę, leidžia plačiau pažvelgti i jos vietą globalioje JAV strategijoje ir nustatyti JAV interesus Lietuvos atžvilgiu kaip Europos valstybės, susieti jos interesus su globaline JAV vykdoma politika bei karu prieš terorizmą. Ypatingai didelė reikšmė bus skiriama NATO vaidmeniui, kadangi ši organizacija yra pagrindinis JAV politikos įrankis tiek Europoje, tiek Baltijos jūros regione, tiek Baltijos šalyse.

\section{JAV globali saugumo strategija}

JAV didžioji strategija iki šiol yra istorinių tradicijų kaip Monroe doktrinos ir naujų idejjų samplaika. Iki Pirmojo pasaulinio karo JAV įtaka Europos žemyne buvo minimali. JAV resursai buvo riboti, o politinè valia kištis į kitų regionų likimą, išskyrus Lotynų Amerikos, neegzistavo.

${ }^{2}$ Center for Strategic and International Studies (CSIS), Institute of International Relations and Political Science, Vilnius, Lithuania's Security and Foreign Policy White Paper, 2002, 1-3. 
Po Pirmojo pasaulinio karo Amerika tęsé neoizoliacinizmo politiką. W. Wilsono žymiausias kūrinys ,Tautų lyga“ pasirodè nepriimtina Kongresui. Kariuomenė, kuri stipriai išaugo 1917-1918 metais buvo visiškai demobilizuota, „buvo iškelti siūlymai panaikinti jūrų pėstininkų pajẻgas, kiti stebėjosi Valstybės departamento reikalingumu. Slaptas biuras, užsiimantis užsienio valstybių naudojamų slaptų kodų dešifravimu, buvo panaikintas. Užsienio prekybos dalis lyginant su BVP sumažejo“"33. Izoliacionistinė Amerikos politika slèpe didžiulị šalies potencialą ir ịtaką, kuri buvo panaudota Antrojo pasaulinio karo metu. Tuomet JAV turèjo ne tik galią, bet ir politinę valią prisiimti lyderystès naštą. W. Pfaffo nuomone, T. Roosvelto pažiūros buvo intervencionistinès, o karas, jo manymu, turèjo parodyti amerikiečių nacijos galybę. Nors oficialiai jis pasisakė prieš karą su Vokietija, tačiau, kaip parašè laiške vienam draugui: ,aš nelabai smulkmeniškas - galima kariauti ir su Ispanija, jei nieko geresnio nebus pasiūlyta“"4.

Antrasis pasaulinis karas simbolizavo izoliacionizmo politikos pabaigą. JAV tampa globaliai veikiančia valstybe, turinčia interesų visuose pasaulio kampeliuose. Jos strateginis tikslas - užtikrinti savo interesų įgyvendinimą - buvo ịprasmintas vèliau susiformavusiose doktrinose.

Po Antrojo pasaulinio karo SSRS išplètè savo įtaką Rytų Europoje ir toliau skverbėsi visomis kryptimis. Kaip atsaką į tai, JAV Eurazijoje sudare valstybių blokus nukreiptus prieš tokią ekspansiją ir garantuojančius JAV įtaką svarbiuose regionuose. P. Taylor žodžiais: „Jei SSRS buvo kaip fortas, tai geriausias elgimosi su juo atvejis yra jị apsupti ir uždèti spaudą. Politiniu žargonu tai žinoma kaip sulaikymo (angl. containment) politika, tai yra antisovietinių blokų žiedo sukūrimas, kaip NATO Europoje, CENTO Vakarų Azijoje ir SEATO Rytų Azijoje“.5 1945 m. Dž. Kennanas paskelbė, kad JAV turi siekti, kad į rusų rankas nepatektų trys strategiškai svarbūs regionai: Jungtinè Karalyste, Reino žemuma ir Japonijos salos. ${ }^{6}$ Taigi JAV strategija aiškiai geografiškai apibrēžè ribas, kur sovietų buvimas buvo nepageidaujamas, o kišimasis į regiono valstybių reikalus turèjo sulaukti JAV karinio atsako.

Dvipoleje pasaulio sistemoje JAV siekẻ dominuoti. JAV strategija, pasak Ch. Layne, nebuvo nukreipta vien tik prieš SSRS, nes tokiu atveju, jau vèliau, po SSRS subyrëjimo, JAV būtų pasitraukusi iš Europos, o NATO būtų atėjęs galas. JAV tolimesnis buvimas Europoje įrodo, kad SSRS faktorius JAV strategijoje vaidino mažesnị vaidmenį, negu buvo iki šiol manoma. ${ }^{7}$ Net ir egzistuojant dvipolei sistemai Šaltojo karo metais, JAV vadovavosi samprata, kad ji užtikrina savo saugumą ne siekdama palaikyti globalų galios balansą, bet dominuodama bei siekdama hegemonijos.

JAV rèmèsi nuostata, kad saugumas pirmiausia remiasi karine galia, todèl geriausia būti pirmaujančia valstybe. Po SSRS žlugimo JAV saugumo saitai su Australija, Taivaniu, Korejja, Turkija ir kitomis sajungininkėmis nè kiek nesumažèjo. Do-

\footnotetext{
${ }^{3}$ Kennedy P. „The Next American Century?“, World Policy Journal, Spring 1999, Vol.16, Issue 1, 53-54.

${ }^{4}$ Pfaff W. „The Question of Hegemony“, Foreign Affairs, Jan/Feb 2001, Vol.80, Issue 1, 221-233.

5 Taylor P. Political Geography. World Economy, Nation-State And Locality. 3th ed., New York: Wiley, 1993, 59.

${ }_{6}^{6}$ Уткин Б. Н. Американская стратегия для ХХІ века, Москва, Логос, 2000, 13.

${ }^{7}$ Layne Ch. „Rethinking American Grand Strategy: Hegemony or Balance of Power in the TwentyFirst Century?", World Policy Journal, Vol. 15, Issue 2, Summer 1998, 8-28.
} 
minavimo siekis, kaip pagrindinis JAV strategijos elementas, išliko ir po Šaltojo karo pabaigos - keitèsi tik jo formos ir ịgyvendinimo būdai. Visų pirma JAV ir toliau, net ir po teroristinių aktų, didžiausią reikšmę teikia kariniam atsakui ị grèsmes savo saugumui. JAV siekia išlaikyti karinị buvimą visose pasaulio dalyse bei būti technologiškai pranašesne už konkurentus.

Antra, JAV siekia išlaikyti savo dominavimą nė viename kontinente neleisdama susidaryti konkuruojančiai jègai ar koalicijai, kuri galètų taptų tuo, kuo seniau buvo SSRS. Geografiškai, kaip ir anksčiau, pagrindinis JAV politikos objektas išliko Eurazija. Kaip sako Z. Brzezinsky, Eurazija yra pati politiškai aktyviausia ir dinamiškiausia planetoje. Neskaitant JAV, šešios didžiausios ekonomikos ir šešios daugiausiai išlaidų gynybai skiriančios valstybès yra Eurazijoje. Tik šiame kontinente yra valstybiu, kurios pajëgios mesti iššŭkị JAV hegemonijai. JAV tikslas - neleisti šiame regione įsivyrauti priešiškai JAV koalicijai ${ }^{8}$.

Ch. Layne nuomone, ,geografiškai ši [dominavimo] strategija ir dabar identifikuoja Europą, Rytų Aziją ir Persų įlanką kaip regionus, kurie JAV turi strateginę reikšmę. Europa ir Rytų Azija yra svarbūs dèl to, kad jose gali iškilti hegemonas, galintis mesti iššūki JAV, o Persų įlanka svarbi dėl savo naftos resursų “9 . Amerikos saugumo garantijos Vokietijai ir Japonijai yra vienos svarbiausių JAV strategijos Europoje ir Rytu Azijoje elementų. Suteikdama garantijas, JAV ịsipareigoja ginti šių šalių interesus, tuo pačiu neleisdama (nesuteikdama preteksto) šioms šalims siekti didžiosios galybės statuso. Ch. Layne nuomone, Vašingtonas norèjo matyti stiprią Europą ir stiprią Japoniją, tačiau jos neturejjo būti tiek stiprios, kad galètų mesti iššūkị pačiai Amerikai. Ypatingai ją neramina Vokietijos iškilimas, kuris gali kelti grèsmę JAV hegemonijai Europoje. ${ }^{10}$

Straforo korporacijos nuomone, ,JAV kovojo per abu pasaulinius karus siekdama vieno tikslo - sutrukdyti Eurazijoje įsivyrauti vienam galios centrui. Logika paprasta - jei vienam centrui leisime manipuliuoti visais žemyno resursais, tai galios balansas dramatiškai pasisuks prieš JAV. Antrojo pasaulinio karo metu, matydama Vokietijos ir Japonijos sajungos pavojingumą, JAV ịsikišo, tiesa, tik paskutiniu momentu. Šaltojo karu metu JAV jau buvo pasimokiusi iš savo klaidų, tad iš karto nusprendè, kad, norint išlaikyti galios balansą Europoje, reikia įsikišti ir pakreipti i̊vykius sau naudinga linkme“.

Trečias, ne mažiau svarbus JAV globalios strategijos bruožas - palaikyti liberalią pasaulinę ekonomiką, kuri, G. J. Ikenberry žodžiais, „pagrįsta institucionalizuotais rinkos demokratijų politiniais santykiais“"11. Tokia strategija turi ir geostrateginių tikslų. JAV vyrauja nuostata, kad ,atvira prekyba, demokratija ir tarptautinés institucijos palaiko viena kitą. Taisyklemis grịsta tarptautinè tvarka, ypatingai, jei tai tvarkai vadovauja Amerika, geriausiai gintu JAV interesus“". ${ }^{12}$ Tarptautinè ekonominè sistema tapo alternatyva galios varžyboms ir konfrontacinių blokų kūrimui pasaulyje. Tokia strategija sukūrè bendradarbiavimo viziją, pagrịstą bendromis vertybėmis, tradicijomis ir stabilumu, kur visi dalyviai turi naudos iš buvimo pasaulinès sistemos dalimi.

\footnotetext{
${ }^{8}$ Бжезинский 3. Великая шахматная доска. Москва, Международные отношенеия, 2001. 43-48.

${ }^{9}$ Layne (note 7).

${ }^{10}$ Ibidem.

${ }^{11}$ Ikenberry G. J. „America’s Imperial Ambition“, Foreign Affairs, Sept/Oct 2002, Vol. 81, Issue 5.

${ }^{12}$ Ibidem.
} 
Apibendrinant - Eurazijoje JAV vykdo hegemonijos per galios balansą politiką, kurios elementai susisieji vieni su kitais ịvairiuose lygiuose:

- Globaliniu mastu, JAV išlaiko hegemoninę politika ir neleidžia iškilti priešininkams Eurazijos kontinente ar susidaryti plačiai antiamerikietiškai koalicijai. Nauda, gaunama iš dalyvavimo tarptautinejje ekonominejje sistemoje, sukuria valstybių interesą išlaikyti šios sistemos egzistavimą bei mažina galimybę mesti iššūkị JAV dominavimui.

- Regioniniu mastu, stabilumas trijose strateginėse teritorijose (Europa, Rytu Azija, Artimieji Rytai) užtikrinamas regioninio galios balanso pagalba. Šiuose regionuose siekiama neleisti iškilti dominuojančiai valstybei ar susidaryti antiamerikietiškų valstybių koalicijai. Europoje galios balansas užtikrinamas išlaikant NATO ir saugumo garantijas Vokietijai, o Azijoje - garantijas Pietų Korejjai, Japonijai ir Taivaniui. Artimujų Rytų regione siekiama neleisti iškilti valstybei, kuri būti pajëgi dominuoti regione ir galètų sutelkti kitas musulmoniškas valstybes ị antiamerikietišką koaliciją, nesvarbu, ar tai būtų Irakas, Iranas, Saudo Arabija, Egiptas ar Libija.

\section{Strategija po Šaltojo karo - interesų paieškos}

JAV didžioji strategija gana aiškiai nustate globalinius politikos tikslus, kurie pagrịsti subalansuoto dominavimo koncepcija. Tačiau regioniniu lygiu JAV interesai nebuvo aiškiai suformuluoti. Jei seniau išoriniai veiksniai, konkrečiai SSRS grèsmé, lèmė JAV užsienio politikos formavimą, tai po Šaltojo karo pabaigos ji tapo vidaus politikos - pramoninių, etninių ir kitų interesų grupių, vidaus politinių koalicijų išvestine.

Kaip pasakè S. Huntingtonas, ,neturèdami nacionalinio identiteto jausmo, amerikiečiai nesugeba tiksliai apibrèžti savo nacionalinių interesų. Dèl šios priežasties jos užsienio politikoje dominuoja subnacionaliniai komerciniai interesai ar transnacionaliniai ir nenacionaliniai etniniai interesai“ ${ }^{13}{ }^{13}$ Po Šaltojo karo pabaigos išorinio priešo nebuvimas trukdẻ konkretizuoti JAV užsienio politikos prioritetus. Jungtinio štabo viršininkas, vèliau tapęs JAV valstybės sekretoriumi, generolas C. Powellas taip apibūdino situaciją: „I'm running out of demons. I'm running out of enemies. I'm down to Castro and Kim Il Sung" ${ }^{\text {"14 }}$.

JAV globalineje strategijoje pagrindinè problema buvo aiškiai nesuformuluoti konkretūs veiklos prioritetai. Nors ir siekdama dominuoti, JAV administracija nesugebẻdavo aiškiai nustatyti konkrečių tikslų bei ịgyvendinti nuoseklią politiką tam tikrų regionų atžvilgiu. J. Nye analizė rodo, kad, pavyzdžiui, „JAV veiksmai, kaip intervencijos Somalyje ar Haityje, buvo daugiau CNN efekto, o ne JAV interesų išraiška"15. Keitèsi požiūris ir ị Rusiją; nors pagrindinis principas liko tas pats skatinti demokratijos plètrą ir stabdyti masinio naikinimo ginklų plitimą - tačiau daugybė lëšų buvo leidžiama programoms, nesusijusioms su prioritetinèmis problemomis, finansuoti.

${ }^{13}$ Nye J. „Redifining the National Interest“, Foreign Affairs, Jul/Aug 1999, Vol. 78, Issue 4, 22-23.

${ }^{14}$ Waltz K. „The Balance of Power and NATO Expansion", University of California, Berkeley,

Center for German and European Studies, Working Paper 5.66, 1998.

${ }^{15}$ Nye, (note 13), 24-27. 
W. Perry ir A. Carteris yra pasiūlę kaip reiktų grupuoti grėsmes JAV saugumui. ${ }^{16}$ Viršuje būtų „A sąrašas“, kur būtų įtrauktos grèsmes, keliančios pavojų JAV egzistencijai, kaip, pavyzdžiui, buvusios SSRS grèsmè. Antrasis „B sąrašas“ apimtų labai svarbias, bet ne egzistencines grèsmes, pavyzdžiui, Iraką ar Šiaurès Korejją. Galiausiai i „ „C sąrašą" būtų įtrauktos kitos svarbios grèsmès kaip Somalis, Kosovas, Bosnija, Ruanda ar Haitis.

J. Nye nuomone šokiruoja tai, kad „C sąrašo” grésmės dominuoja JAV politikoje. W. Perry ir A. Carteris manè, kad taip atsitiko dèl „A sąrašo” tipo grèsmių išnykimo. Kita priežastis, J. Nye nuomone, yra ta, kad „informaciniame amžiuje „C“ grèsmès yra žiniasklaidos dèmesio centre. Dramatiški kenčiančių žmonių portretai televizoriaus ekrane geriau patraukia žiūrovų dėmesį, nei lètas Rusijos „,veimarizavimas“, Kinijos hegemonizmo didejimas, ar aljanso su Japonija būtinybė.“17 Dèl to JAV politika regionuose, kur ji neturi didelio intereso, tapdavo sunkiai prognozuojama ir neretai rodydavo vidines kovas Amerikos administracijoje. Svarbūs ir daug diskusijų sukèlę sprendimai - NATO plètra, Kyoto protokolas, ABM sutartis ir požiūris ị ginklų kontrolès mechanizmus, Tarptautinio baudžiamojo teismo statutas tapdavo vidinių žaidimų objektu, o ne JAV nacionalinių interesų išraiška. Tokia situacija turèjo svarbių pasekmių VR ir Šiaurès Europos regionams - JAV politika jų atžvilgiu pasižymėjo nenuoseklu$\mathrm{mu}$, o parama regiono valstybėms atspindẻdavo jų galimybes mobilizuoti politinę paramą pačioje JAV viduje. Išorinės problemos rodès besą tik nereikšmingi tolimų ịvykių atgarsiai. Tai tęsési iki $2001 \mathrm{~m}$. rugsèjo 11 dienos.

\section{Antiterorizmas - naujas dominavimo etapas}

Teroristiniai išpuoliai turèjo didžiuliụ pasekmių tarptautinei politinei sistemai. Visu pirma tai sustiprino JAV pasiryžimą dominuoti pasaulyje, JAV neatsitraukè į izoliacionizmą, kaip buvo baiminamasi, G. W. Bushui atëjus ị valdžią. Netgi atvirkščiai, dèl tarptautinio terorizmo pobūdžio, JAV sustiprejo politinè valia bandyti veikti pasaulyje vykstančius procesus ir tam panaudoti milžinišką ekonomini ir karinị potencialą.

Naudojant W. Perry ir A. Carterio terminologiją, JAV atsirado „A“ tipo grèsmé, kuri sutelkẻ JAV politinį elitą. Jei iki šiol užsienio politika likdavo marginaline problema, tai dabar išoriniai faktoriai tapo svarbia JAV vidaus politikos sudedamaja dalimi. Konkretizavus JAV užsienio politikos prioritetus, JAV politika tapo aiškesnè ir labiau nuspejjama.

JAV administracijos kova prieš terorizmą paskelbta užsienio politikos prioritetu. JAV vykdè karinę kampaniją Afganistane, kuri ateityje gali persimesti ir į kitas šalis. Iraną, Iraką, ir Šiaurès Korèją G. W. Bushas paskelbẻ blogio ašies valstybèmis ir pažadejo imtis visų priemonių šiam blogiui neutralizuoti. Siekdama apsiginti nuo balistinių raketų, JAV nutraukẻ Priešraketinės gynybos sutartį ir metė didžiulius resursus kurti priešraketinės gynybos skydą.

JAV atsakas ị teroristines atakas (tiek slypintis ekonominis ir karinis potencialas, tiek valia veikti) parode jos galimybę vienašališkai vienu metu projektuoti galią į daugelị pasaulio regionų bei dar labiau sustiprino JAV pozicijas pasaulio politikoje. S. Brookso ir W. Wohlfortho skaičiavimais, JAV karinis pranašumas yra

\footnotetext{
${ }^{16}$ Ibidem.

17 Ibidem.
} 
toks ryškus, kaip niekada anksčiau: JAV gynybai išleidžia daugiau nei kitos 15-20 didžiausių karinių galybių kartu. JAV turi branduolinị pranašumą, geriausias oro pajègas ir laivyną, galintị projektuoti galią po visą pasaulį. JAV sẻkmingiausiai pritaiko karinėms technologijoms naujausius komunikacijos pasiekimus ir turi galimybes preciziškai tiksliai atakuoti taikinius visame pasaulyje. JAV išleidžia gynybos moksliniams tyrimams daugiau nei kitos šešios šalys kartu. Visą šị pranašumą JAV turi išleisdama gynybai tik 3,5 procento nuo $\mathrm{BVP} \mathrm{P}^{18}$.

Toks JAV dominavimas S. Brookso ir W. Wohlfortho nuomone, tegali būti sulyginamas su JAV dominavimu Antrojo pasaulinio karo pabaigoje. „Jokia kita galia pasaulio istorijoje savyje netelke tokios dalies pasaulio bendrojo produkto, investicijų ir išlaidų naujosioms technologijoms " ${ }^{\text {"19 }}$. 1999 m. JAV gavo trečdali pasaulio tiesioginių užsienio investicijų bei leido moksliniams tyrimams daugiau nei septynios po jos sekančios valstybès kartu ${ }^{20}$.

Vertybinis dominavimas lieka viena iš JAV galios sudedamujų dalių. C. Rice Foreign Policy žurnale išspausdintame programiniame respublikonų užsienio politikos straipsnyje be jokios autoironijos tvirtina, „JAV vertybès yra universalios. Žmonės nori sakyti tai, kas jiems patinka, garbinti tai, ką nori ir rinkti tuos, kurie juos valdys. Šias vertybes lengviausia pasiekti, kai tarptautinis balansas yra tų pusejje, kurie šias vertybes išpažista“21. JAV daug labiau ėmè skatinti demokratijos raidą kituose žemynuose.

VR ir Šiaurès Europos regionams ypatingai svarbus yra vertybių reikšmès sustiprẻjimas JAV užsienio politikoje po rugsèjo $11 \mathrm{~d}$. teroristinių aktų. Iki to laiko amerikiečiai mažai kreipè dẻmesio ị kultūrinius, religinius, kalbinius žmonių skirtumus. Amerika buvo tarsi didelis katilas, kuriame tie skirtumai susimaišydavo ir išnykdavo, todèl amerikiečiams buvo sunku suprasti, kodẻl taip neturètų atsitikti ir kitur. Teroristų paieška ir aiški jų sąsaja su islamo fundamentalizmu bei paieška atsakymo ị klausimą, kodèl tie žmonès užpuolè Ameriką?, apvertẻ daugelį anksčiau egzistavusių iliuzijų aukštyn kojomis. Mažai tikètina, kad teroristai sprogdindami dangoraižius turẻjo geostrateginių interesų. Jie puolè dẻl to, kad jų priešininkai mąstè kitaip, išpažino kitas kultūrines vertybes, turejo kitokị pasaulio supratimą.

Todèl panašias, ,,amerikietiškas vertybes“ išpažįstančios šalys tapo dar vertingesnèmis sajungininkẻmis, o vertybių sklaida - dar vienu frontu prieš terorizmą. Nors ir būdama viena iš JAV dominavimo sudedamụjų dalių, vertybių plètra kartu su tradicine geopolitine logika tampa vis svarbesniu argumentu, priimant svarbius VR ir Šiaurès Europos regionams sprendimus.

Politinis, ekonominis, vertybinis ir karinis dominavimas leidžia S. Brooksui ir W. Wohlforthui teigti, kad ,JAV dominavimas savo visapusiškumu skiriasi nuo kitų dominavimo etapų. Nei Prancūzija, nei Didžioji Britanija, nei jokia kita pasaulio imperija nèra lenkusi savo konkurenčių visais kriterijais: tiek ginklais, tiek ekonomika, tiek masine kultūra, tiek naujausiomis technologijomis. Visi ankstesni hegemonai tu-

\footnotetext{
${ }^{18}$ Brooks S., Wohlforth W. „American Primacy in Perspective“, Foreign Affairs, July/August 2002. Vol. 81, Iss. 4.

${ }^{19}$ Ibidem.

${ }^{20}$ Рогов С. Доктрина Буша и перспективы Российско-Американских отношений. Вашингтон стремится не допустить появления в ХХІ веке равного США по силе противника, Независимое военное обозрение, N. 14, 0504 2002, 9, http://nvo.ng.ru/concepts/2002-04-05/1_doctrine.html

${ }^{21}$ Rice C. „Promoting the National Interest“, Foreign Affairs, Jan/Feb 2000, Vol. 79, Issue 1, 45-62.
} 
rèjo sritis, kur jų dominavimas buvo lengvai pažeidžiamas, o konkurentai galèjo mesti iššūkị hegemoninei valstybei“'22. JAV nesimato požymių, kad dominavimas turètų neigiamų pasekmiu jos vidaus stabilumui. Jai pasisekè išvengti to, ką P. Kennedy knygoje „Rise and Fall of Great Powers “vadina imperial overstrech (angl.) - JAV ekonominio augimo prognozès daug žada, investicijos didejja, o karinis biudžetas pastoviai auga.

Tarptautinėje sistemoje nusistovi ir stiprèja stabili vienpolè struktūra, kur nè viena valstybė negali ir neturi išteklių mesti iššūkio dominuojančiai galybei. JAV dominavimas toks akivaizdus, kad pasak C. Rice, „Žvelgiant iš teorinių pozicijų, realistai pasakytų, kad, kaip atsvara prieš JAV dominavimą, turètų susidaryti priešiškų valstybių koalicija. Tačiau dabar vyksta atvirkščiai - kitos valstybės stengiasi kurti produktyvius bendradarbiavimo santykius su JAV“23.

JAV dominavimas atsispindi ir bandomose formuoti naujose doktrinose. Štai R. Hasso, JAV valstybės departamento Politikos direktoriaus, nuomone, sulaikymo (angl. containment) didžiają strategiją pakeičia ịpareigojančio suverenumo (angl. limited sovereignty) doktrina. „Suverenumas reiškia įsipareigojimus. Pirma, nežudyk savų žmonių. Antra, neremk teroristų. Jei vyriausybė nesugeba įvykdyti šių reikalavimų, tai ji praranda tam tikrus suverenumo teikiamus privalumus" ${ }^{\text {"24 }}$.

Stratfor žiniomis, antiteroristinès kampanijos metu JAV Gynybos sekretorius D. Rumsfeldas suteikẻ JAV specialiosioms pajëgoms teisę atlikti operacijas tų valstybių teritorijose, kurių vyriausybės atsisako bendradarbiauti su JAV ${ }^{25}$. Slaptos operacijos gali būti atliekamos net neinformuojant tos šalies vyriausybės, jeigu pastaroji atsisako bendradarbiauti su JAV administracija.

Panašūs pareiškimai ir veiksmai aiškiai demonstruoja JAV hegemonijos didèjimo laipsnị, kai vienas iš pagrindinių tarptautinès teisés principų yra skirtingai traktuojamas, remiantis kitaip suprantama suverenumo doktrina bei JAV užsienio politikos prioritetais. Nauji pokyčiai rodo, kad JAV turi pakankamai valios ir galios, kad galėtų siekti savo politikos interesų tam tikros valstybės atžvilgiu, neatsižvelgdama ị kitų valstybių interesus, kartais net prieš viso pasaulio valią, kaip tai atsitiko, pasitraukiant iš ABM sutarties ar atsisakant ratifikuoti Kyoto protokolus.

\section{Europa JAV strategijoje}

Iš strategiškai svarbių regionų JAV globalinèje strategijoje Europai yra teikiama didžiausia reikšmė. Tokia JAV nuostata išreiškia tiek geopolitini, tiek vertybini jos politikos matmenị. $2002 \mathrm{~m}$. priimtoje JAV nacionalinio saugumo strategijoje sakoma, kad moderniame pasaulyje „egzistuoja mažai ilgalaikių darbų, kuriuos JAV galètų atlikti viena, be savo sajungininkių Kanadoje ir Europoje [...]. Europa taip pat yra dviejų svarbiausių tarptautinių organizacijų - NATO ir ES - vieta“"26. Europa suvokiama kaip demokratinių vertybių židinys, pagrindinis Amerikos sajungininkas,

\footnotetext{
${ }^{22}$ Brooks, Wohlforth (note 18 ).

${ }^{23}$ Lemann N. „The Next World Order: The Bush Administration May Have a Brand-new Doctrine“, The Newyorker, (žiūrèta 200204 01).

${ }^{24}$ Ikenberry (note 11).

${ }^{25}$ Strategic Forecasting Rumsfeld Pushes the Envelope with Forces Proposal, Global Intelligence

Update, (žiūrèta 200208 12), http://www.stratfor.com

${ }^{26}$ The National Security Strategy of the United States of America, September 2002, 25.
} 
igyvendinant didiji žmonijos projektą, pavadinta demokratija.

Europa išlieka svarbiausia JAV sajungininke įvairiais aspektais: kultūra, karinèmis pajëgomis, ekonomika. Tačiau sajungininkès statusas nereiškia, kad Europa turi kelti grèsmę Amerikos dominavimui. JAV tikslas - pakankamai stipri Europa, kad būtų gera sajungininkè, bet ne per daug stipri, kad galètų kelti sąlygas Amerikai ir dominuoti globaliniame galios žaidime.

Ekonominiu požiūriu Europa išlieka svarbia JAV prekybos partnere ir didžiausia investuotoja i jos ekonomiką. Pagal US Census Bureau: Statistical Abstract of the United States, $2001 \mathrm{~m}$. Europos valstybiu investicijos į JAV ekonomiką sudare 69 procentus visų užsienio investicijų antroje vietoje liko Azijos šalys su 17 procentų ir Kanada su 8 procentais investicijų. Amerikiečiai patys mažiau, bet vis tiek daugiausia investavo į Europos šalis. Joms teko 52 procentai amerikiečių investicijų, o Lotynų Amerikai teko 20 procentų, Azijai 16 procentų, Kanadai 10 procentų amerikiečių investicijų.

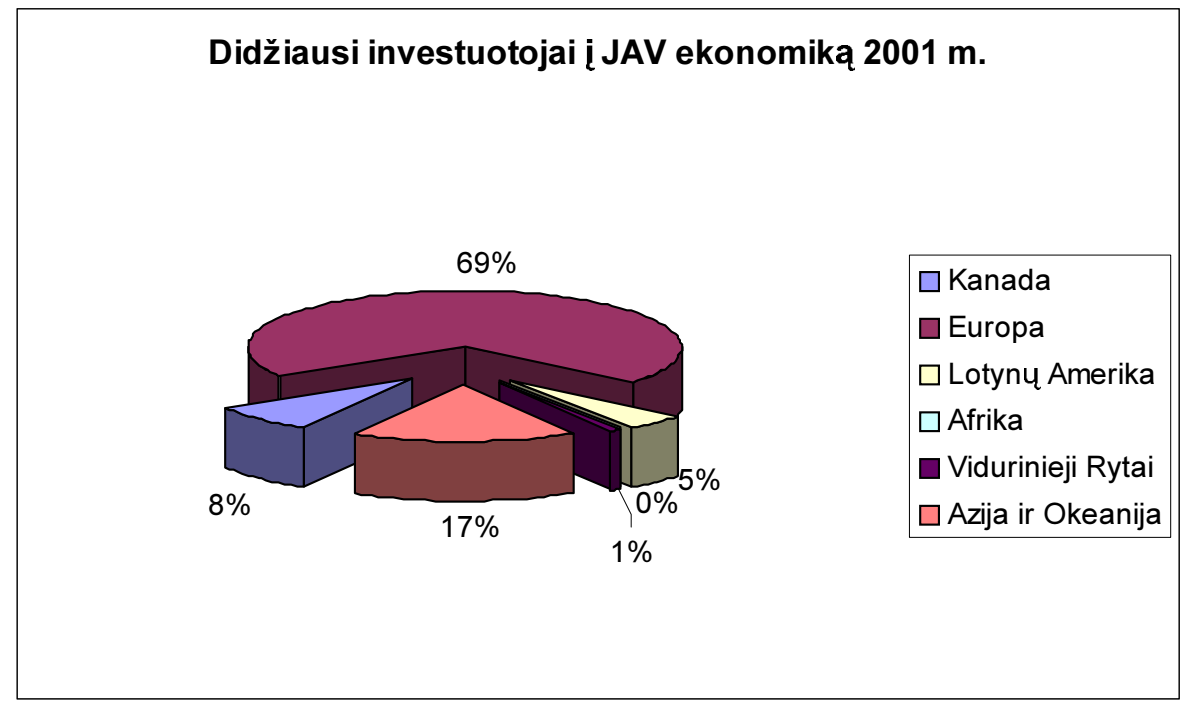

2001 Statistical Abstract of the United States / Foreign Trade Division, U.S. Census Bureau, Washington, http://www.census.gov/prod/2002pubs/01statab/stat-ab01.html 
42

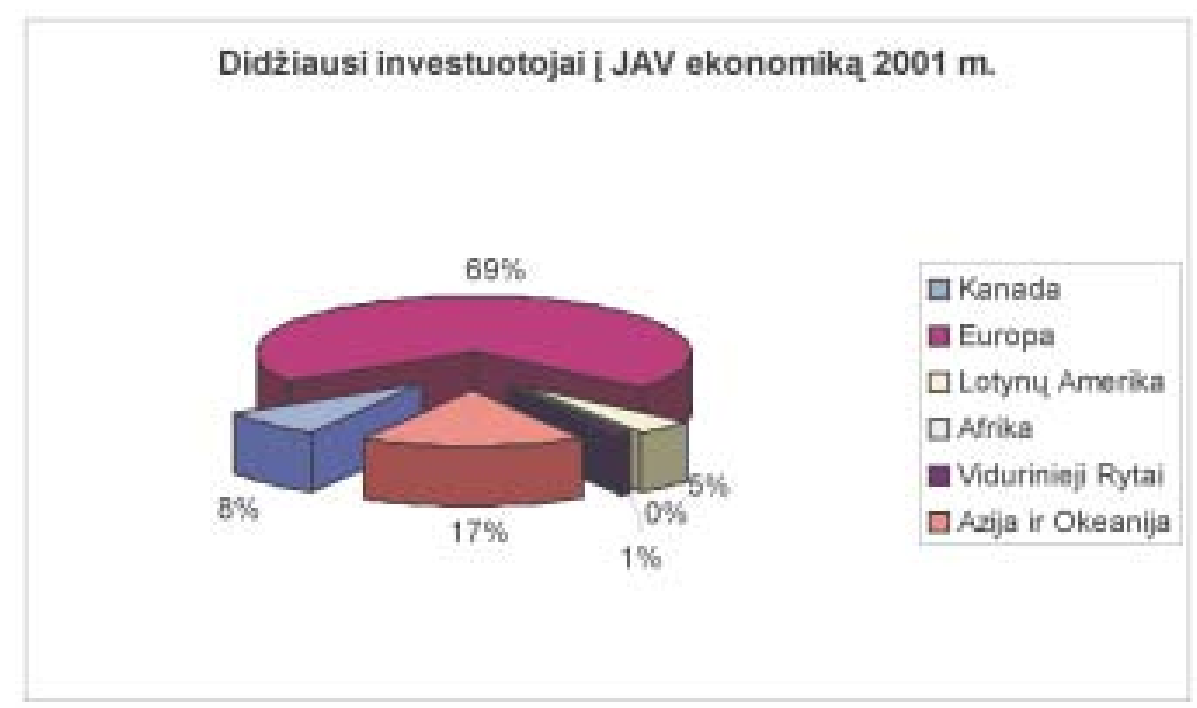

2001 Statistical Abstract of the United States / Foreign Trade Division, U.S. Census Bureau, Washington, http://www.census.gov/prod/2002pubs/01statab/stat-ab01.html

Europos valstybės išlieka viena svarbiausių JAV užsienio prekybos partnerių -nors per pastaruosius dešimtmečius ją išstūmè iš pirmosios vietos kiti regionai, tačiau, kaip vieningas prekybinis blokas, ES kartu su Kanada ir Meksika užima pirmaujančias pozicijas.

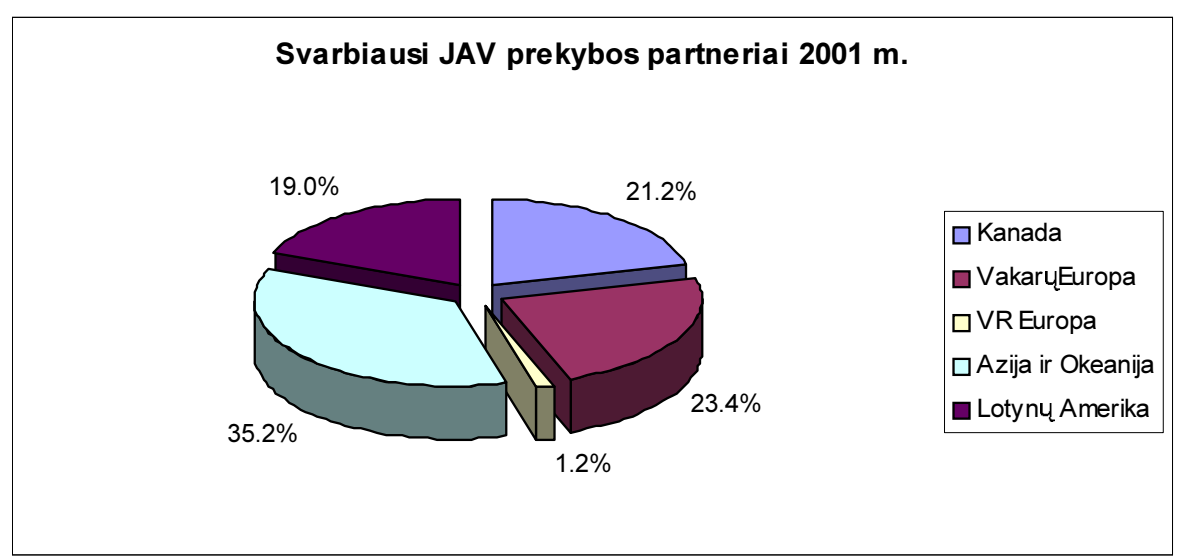

Foreign Trade Division, U.S. Census Bureau, Washington, 2002, http://www.census.gov/foreigntrade/Press-Release/current_press_release/exh6as.txt

Ekonomiškai stipri, tačiau kariniu požiüriu silpna, Europa, K. N. Waltzo nuomone, „tarptautinejje politikoje palyginus su JAV Europa lieka politiniu nuliu“27. Šaltojo karo metais sukurtos karinès struktūros negali būti panaudotos naujoms grèsmėms atremti. Europos valstybiu kariuomenèms reikalingas modernizavimas ir pertvarkos, kuriųigyvendinimui trūksta tiek politinès valios, tiek finansinių resursų. Net ir palyginus mažo dydžio kuriamoms Europos greitojo reagavimo pajègoms trūksta kai kurių esminių pajègumų, kurie ịgalintų europiečius kovoti tomis pačiomis sąlygomis kartu su amerikiečiais.

${ }^{27}$ Waltz (note 14). 
Europos karinis silpnumas neleidžia siekti lygiavertès partnerystès ar net konkuruoti su JAV. Antra vertus, JAV nenaudinga ir visiškai silpna Europa, kuri negali padèti, kai JAV vykdo karines operacijas. Kosovo kampanijos metu 70 procentu lèktuvų, 80 procentų amunicijos ir t.t. skyrè amerikiečiai. Dar didesnis europiečių atsilikimas išryškejjo Afganistano kampanijos metu. Nors europiečiu gynybos biudžetas sudaro 60 procentų amerikiečių biudžeto, Europos ir JAV karinès galios santykis apytiksliai vertinamas kaip 1 su $10 .^{28}$

Europos karinis atsilikimas skatina JAV pasitikèti savo jègomis ir mažiau remtis europiečių kontribucija. Nors C. Powellas sakydamas savo pirmają savo kalbą senate, paskelbė: „NATO yra nesugriaunama. Susilpninus NATO, susilpnès Europa, o tuo pačiu ir Amerika “29 , tačiau operacijose Afganistane ir Irake JAV rémėsi ne aljansu, bet „norinčiü“ koalicija. NATO kaip organizacijos pajègumai nebuvo panaudoti. Antiteroristiné kampanija rodo JAV polinkị i vienašališkus veiksmus, be formalių sajunginių įsipareigojimų, remiantis atskirų valstybių kontribucija.

Europos karinis silpnumas veikia VR ir Šiaurès Europos situaciją. JAV susidomèjimas VR ir Šiaurès Europa yra bendro JAV intereso Europoje išvestinè. Transatlantinio ryšio silpnèjimas gali reikšti JAV ịsipareigojimų mūsų regione sumažejimą. CSIS ir VU TSPMI rengtoje studijoje pažymima, kad „Lietuvai labiausiai nepalankus scenarijus yra JAV nusišalinimas nuo Europos reikalų ir vienašališki veiksmai kovoje prieš terorizmą. Tai sumažintų JAV aktyvumą regione, o NATO virstų neveiksminga organizacija ${ }^{\text {“30 }}$.

Pasaulineje arenoje JAV gali pasitelkti tik dviejų valstybių - Didžiosios Britanijos ir Prancūzijos - pagalbą. Tik šios valstybès turi pajègas, leidžiančias projektuoti galią toli už jų teritorijos ribų. Nors geografiškai Europos reikšmė kovoje prieš terorizmą sumažèjo, tačiau europiečiu pagalba reikalinga vèlesnèse konflikto stadijose. Operacijoje „Tvirta taika“ Afganistane iš 15 tūkstančiu karių didžioji dalis priklause JAV sajungininkėms, t.y. daugiau nei 8 tūkstančiai. ${ }^{31}$ Iš tiesų tai buvo Europos valstybių kontribucija, kadangi iš kitų JAV sajungininkių tik penkios valstybės - Australija, Japonija, Jordanija, Naujoji Zelandija ir Pietų Koreja - paremė operaciją ne tik politiškai, bet ir pajègumais. JAV teoriškai turèjo galimybę operaciją užbaigti viena, tačiau be sajungininkių paramos ji būtų susidūrusi su pajègų trūkumu. Dar didesnè našta tenka Europos valstybėms Afganistane, atstatant šalį, skiriant fondus prikelti šalies ekonomiką ir gerinant padètį žmogaus teisių srityje.

JAV strategijoje NATO vaidina ypatingai svarbų geostrateginị vaidmenị. Suteikdama saugumo garantijas Europos šalims, JAV neleidžia Europoje sukurti savarankiškai kolektyvinès gynybos organizacijai, panašiai ị tai, kuo Prancūzija norèjo paversti Vakarų Europos Sajungą. JAV nenori, kad ES ịgytų stiprų karinį komponentą, kuris paverstų šią organizaciją vientisu geopolitiniu subjektu, galinčiu mesti iššūkị JAV. JAV valstybės sekretoriaus C. Powello nuomone, ,JAV sveikina Europos vals-

\footnotetext{
${ }^{28}$ Chalmers J. NATO Banks On Capability To Salvage Credibility Reuters, 18 Nov 2002.

${ }^{29}$ Testimony of Secretary of State - designed Collin L.Powell Prepared for confirmation hearing of the US Senate Committee on Foreign Relations, (žiūrèta 200101 17), http://www.senate.gov/ $\sim$ foreign/testimony/wt_powell_011701.txt

${ }^{30}$ Center for Strategic and International Studies (CSIS), Institute of International Relations and Political Science, Vilnius, (note 2), 53.

${ }^{31}$ US Department of Defense International Contributions to the War Against Terrorism, Fact Sheet, revised (žiūrèta 200206 14), http://www.defenselink.mil/news/Jun2002/d20020607contributions.pdf
} 
tybių karinės galios didejjimą. JAV palaikys šias pastangas tuo atveju, jei jos stiprins, o ne silpnins NATO“32 . JAV nori išlaikyti NATO kaip Europos saugumo organizaciją, o ne leisti atsirasti savarankiškam ES matmeniui, kurioje amerikiečiai nevaidintų jokio vaidmens.

ES viduje JAV siekia neleisti dominuoti vienai iš jos valstybių, pavyzdžiui, Vokietijai. Toks dominavimas Amerikai reikštų, kad ES viduje atsirastų politinis lyderis, galintis kalbėti visos ES vardu ir valdyti didžiulius ekonominius resursus. JAV siekia kalbėtis su kiekviena Europos valstybe atskirai, o ne su vieningu bloku. Lygiai taip pat JAV nenori skatinti ES centralizacijos ir tolimesnès integracijos. Vieningas ES blokas su pastovia struktūra ir kvazivyriausybe taptų, jeigu ne priešininku, tai bent konkurentu, centru, galinčiu suardyti vienpolę pasaulio struktūrą. Remdamasi tokia pačia logika, JAV nenori skatinti platesnio ES-Rusijos suartèjimo. Tokia sajunga sujungtų ekonominius ir karinius Europos valstybių bei Rusijos resursus ir potencialiai sudarytų grèsmę JAV nacionaliniams interesams. Tuo pačiu JAV skatina Rusijoje demokratines reformas ir remia Europos valstybių pastangas šia kryptimi.

Taigi globalioje JAV strategijoje iš Europos laukiama pritarimo ir pagalbos, bet ne konkurencijos. Pastangos iš ES padaryti savarankišką galios centrą arba galimybė Europoje įsivyrauti vienai valstybei, automatiškai sulauks JAV neigiamos reakcijos. Tokia JAV politika diktuoja ir jos požiūrị i Lietuvą ir Šiaurès ir Rytų Europos regioną.

\section{Regioninis požiūris - VR ir Šiaurès Europos vieta JAV strategijoje}

Dẻl specifinės Europos vietos JAV strategijoje, kiekviena valstybè, turinti įtaką galios balansui senajame žemyne ir dalyvaujanti sprendimų priemmimo procese, tampa svarbia JAV politikos dalimi. Dẻl savo dydžio ir pajėgumų neabejotinai svarbiausiais JAV partneriais išlieka Didžioji Britanija, Vokietija, Prancūzija, o sprendžiant Artimujjų Rytų problemas - Turkija. Tačiau dèl ypatingo ES spendimo prièmimo mechanizmo mažos valstybės kontinente igyja neproporcingai daug įtakos. Ypatingai tai taikytina Šiaurès Europos šalims. Todèl JAV politika VR ir Siaurès Europos valstybių atžvilgiu bus konstruojama, atsižvelgiant ne tiek ị jų dydį, kiek i j jų būsimą įtaką ir aktyvumą Europoje.

Dẻl ribotų resursų, o tuo pačiu ir galimybių savarankiškai prisidèti prie JAV politikos pasaulyje ir Europoje igyvendinimo, JAV mato Lietuvą ir jos kaimynes kaip vientisą regiono dalį. Būtent todèl Lietuvos svarba JAV užsienio politikai iš dalies gali būti prilyginta to regiono, kuriam priklauso Lietuva, svarbai. Didejjant VR ar Šiaurès Europos reikšmei, automatiškai didejja ir Lietuvos šansai sulaukti didesnio dèmesio Vašingtone ir gauti Amerikos paramą aktualioms Lietuvai problemoms.

Specifiškai JAV politika tiek Šiaurės Europos, tiek VR Europos regiono atžvilgiu yra bendros JAV Europos politikos dalis, kuriame JAV siekia:

- kovoje su terorizmu bei masinio naikinimo ginklo plitimu gauti valstybiu paramą (tiek politiškai, tiek ekonomiškai, tiek karinėmis pajëgomis);

- užtikrinti amerikietiškų vertybių ir demokratijos plètrą pasaulyje ir mūsų regione, iskaitant Rusiją, Baltarusiją, Ukrainą, Kaukazą, Balkanus;

\footnotetext{
${ }^{32}$ Testimony of Secretary of State C. Powell (note 29).
} 
- išlaikyti dominavimą Europoje (stiprinti transatlantinį ryšį , neleisti atsirasti karinei ES dimensijai, o pačiai organizacijai pavirsti savarankišku galios centru, neleisti iškilti ES viduje dominuojančiai valstybei bei sudaryti strateginę partnerystę su Rusija, fiksuoti Rusijos sienas ir neleisti atsirasti naujai ekspansionizmo bangai);

- išlaikyti ekonominius ryšius su ES, garantuoti investicijų srautus, plèsti rinką gynybos pramonès produkcijai.

JAV konstruoja politiką mūsų regiono ir šalies atžvilgiu taip, kad atitiktų šių globalių interesu igyvendinimą. Tai tinka tiek Šiaurès Europos, tiek VR Europos regionams. Dèl savo geopolitinès padèties ypatybių, kiekviena valstybè turi savo specifinę rolę ir užduotis JAV strategijoje, tačiau šis sąrašas aiškiai demonstruoja, ko JAV nori ir tikisi iš Lietuvos ir jos kaimynų.

Savo ruožtu mūsų regiono valstybès taip pat aiškiai mato, kokią rolę JAV turi vaidinti regione, kokia turi būti jos politika tam tikrų valstybių ar reiškinių atžvilgiu. VR ir Šiaures Europos regionus vienijantis faktorius yra jų proamerikietiška orientacija, kuri kyla iš to, kad saugumo požiūriu regiono valstybès yra priklausomos nuo JAV, be kurios neįsivaizduoja Europos saugumo.

Ypatingai JAV su VR ir Šiaurès Europą sieja noras neleisti Europoje iškilti hegemonui, valstybei, valdančiai didžiają dalį žemyno resursų, nesvarbu, ar tai būtų Vokietija, ar Rusija, ar kita valstybė. Šioje strategijoje svarbią vietą užima VR Europa, kuri istoriškai buvo Vokietijos ir Rusijos įtakos pasidalinimo objektu. A. Liebich nuomone, ,Teutonų ordinas, Prūsija, hitlerininkai randa panašų atvaizdą regiono gyventoju galvose, kaip ir totoriai, moskoviečiai ar sovietai. VR Europos šalys faktiškai turi tik dvi strategines alternatyvas - būti periferijoje arba būti ,per vidurị“. Vokiečių istorikai šias šalis kartais vadina „Mitteleuropa“, reiškiančią „,vidurinę“"Europą. VR Europos šalių politikai savotiškai interpretavo šią sąvoką, suteikdami jai kitą atspalvị. Taip gimè terminas Central Europe (angl.). Vis dèlto būti viduryje ar centre (angl. in the centre or in the middle) nèra tas pats. Centrinès valstybès pačios formuoja istoriją, tuo tarpu vidurinès tėra jos objektas" ${ }^{\text {"33 }}$. Dél tokios specifinès istorinès padèties vidurio ir rytų europiečiai vengia tiek Rusijos, tiek Vokietijos iškilimo. Dẻl to A. Liebichas teigia, kad netgi tie vidurio europiečiai, kurie nèra entuziastingi NATO šalininkai, nori būti Amerikos aljanso dalimi ${ }^{34}$. Jie nemėgsta rusų, yra atsargūs su europiečiais ir myli amerikiečius. Būtent jiems taisyklè, galiojusi Europoje prieš penkiasdešimt metų, yra ypatingai aktuali „, angl. keep russians out, americans in and germans down “. Jiems NATO plètra garantuotų ne kažkurios iš kontinentinių valstybių, o JAV dominavimą Europoje ir regione, kuris ilgą laiką buvo Rusijos ir Vokietijos varžybų vieta. Be amerikiečių regione Lietuva, kaip ir kitos regiono valstybés, vèl taptų Rusijos ir Vokietijos padidejusios įtakos zona.

Šiaurès Europos valstybių noras matyti JAV Europoje yra diktuojamas panašių geostrateginių motyvų. Šaltojo karo metais karinis jų saugumas buvo priklausomas nuo JAV saugumo garantijų ir gebẻjimo neutralizuoti SSRS įtaką bei palaikyti subtilų Šiaurès balansą. Ši priklausomybė iki šiol vaidina svarbų vaidmenị Šiaurès šalių strategijoje. Ryšiai su JAV bei didžiule parama Baltijos šalims yra svarbūs šios strategijos elementai

${ }^{33}$ Liebich A. East Central Europe: The Unbearable Tightness of Being, Yale University, Historical Roots of Contemporary and Regional Issues, Occasional Paper Series, No. 15, 1998.

${ }^{34}$ Ibidem. 


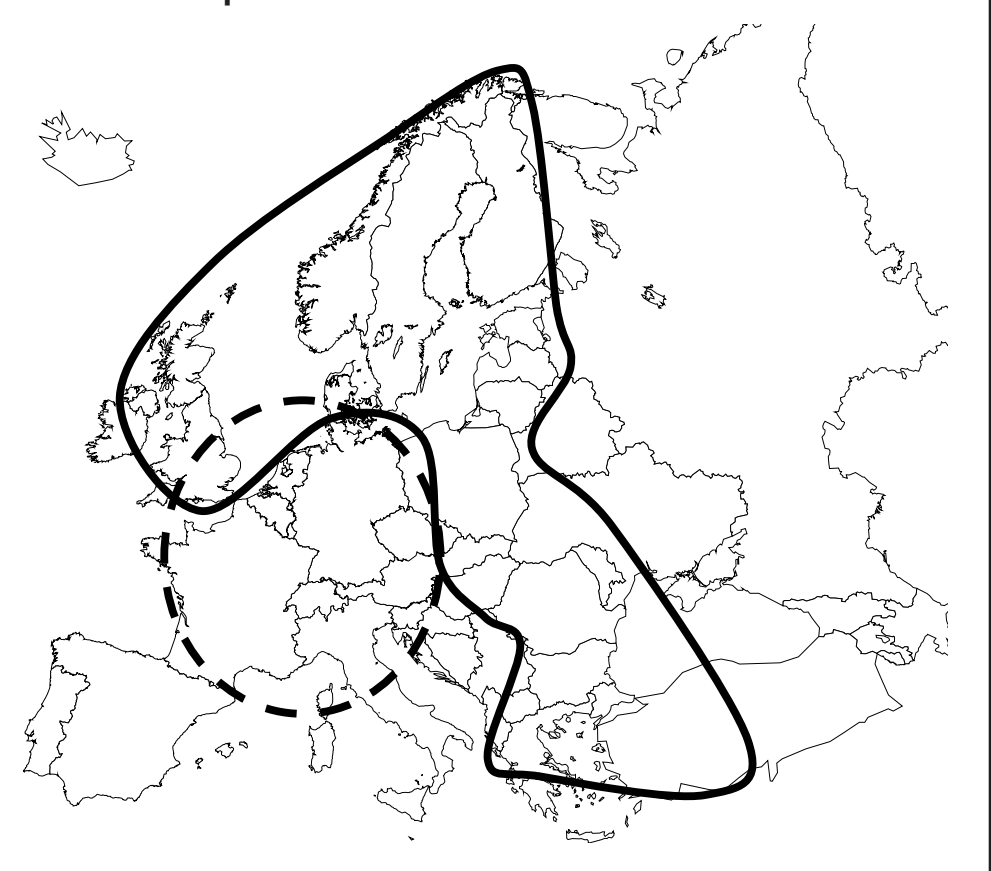

Antras charakteringas JAV-VR ir Šiaurės Europos santykių bruožas - ryški galios asimetrija tarp abiejų pusių. JAV kalba su regiono valstybemis iš stipresniojo pozicijų. VR ir Šiaurès Europos šalys negali amerikiečiams pasiūlyti tokių pajëgumų, be kurių JAV negalètų išsiversti. Antiteroristinè kampanija yra puikus tokio santykio pavyzdys. JAV vertina šalių dalyvavimą, tačiau jų atsisakymas dalyvauti jos nesustabdytų. Regiono valstybių reikšmè galètų išaugti, jeigu jos turètų tokių pajègumų, kurių neturi kitos valstybės ir pati Amerika arba egzistuotų didžiulis tų pajëgumų trūkumas. Tai galètų būti žvalgybinè informacija, patirtis, dirbant su tam tikrais specifiniais regionais, specializuoti kariniai daliniai, aukštos technologijos produktai ir panašiai.

Keičiasi ir geografinè VR ir Šiaurès Europos reikšmė JAV strategijoje. Jeigu iki šiol regionas buvo suprantamas daugiausia kaip Rusijos stabdymo ịrankis, tai JAV ịsitraukus ị karą prieš terorizmą, regionas ịgavo visiškai kitą statusą. Iš konfrontacijos zonos VR ir Siaurès Europa tampa Amerikos interesų ir vertybių plètros įrankiu. Geografiškai Lietuva ir jos kaimynès yra nutolusios nuo karštų regionų, todèl JAV, išskyrus lèktuvų perskridimus, nereikalinga jų teritorija perdislokuojant karinius dalinius. Terorizmo židinių, stovyklų regione neaptikta. Masinio naikinimo ginklo regione nèra ir, išskyrus Rusiją, jis nekelia didelio pavojaus. Finansiniai teroristų šaltiniai daugiausia buvo laikomi kitų šalių, o ne VR ar Šiaurès Europos valstybių bankuose, ekonominiai ryšiai su arabų šalimis mažai išplètoti. Geografiškai JAV prioritetiniu regionu tampa Artimieji Rytai ir Persijos įlankos regionas, naują reikšmę įgauna Vidurio ir Pietų Azijos valstybès (Uzbekija, Tadžikija, Afganistanas, Pakistanas, Kirgizija). 
Geografinis atitolimas nuo konfliktų ir įtampos zonų reiškia pakitusį regiono vaidmenį JAV strategijoje. Jei iki šiol JAV skyrẻ daugiausia dẻmesio mūsų regiono stabilizavimui, dabar ji laukia paramos globaliniams tikslams ịgyvendinti. Pamažu mūsų regionas iš saugumo vartotojo virsta į saugumo eksportuotoją. Nuo regiono valstybių aktyvumo ir pastangų eksportuojant saugumą į kitas šalis priklauso regiono galimybės kaip nors veikti JAV administraciją.

\section{Vertybių sklaida}

JAV dominavimo strategijoje ypatingą vietą užima vertybių plètra. Amerikiečių pasaulio vizija remiasi prielaida, kad demokratinès valstybès nekariauja tarpusavyje, o laisva prekyba ir atviros sienos veda ị šalių gerovę. Teroristai mete iššūkị didžiajam Amerikos projektui - pasauliui, kur vyrauja laisva prekyba, žmogaus laisvès ir demokratija. Jie paryškino liniją, kuri skiria amerikiečius nuo kitokio pobūdžio kultūrų ir suartino su tais, kuriems tarptautinè žmogaus teisių deklaracija nėra vien tuščias popieriaus lapas.

J. Kurthas savo straipsnyje „The next NATO: Building an American Commonwealth of Nations" pastebejjo, kad iki šiol demokratinès Amerikos idealai sugebejo pasiekti tik mažumą pasaulio teritorijos ir dar mažiau gyventojų masès. Demokratijos zona apima tik Europą, didžiają dalį Lotynų Amerikos, kai kurias Rytų Azijos šalis, Australiją ir Naujają Zelandiją. ,Turbūt neatsitiktinai šie regionai apima tą pasaulio dalị, kur prieš penkiasdešimt metų buvo sukurta JAV aljansų sistema“" (NATO, OAS, ANZUS bei dvišalès sutartys su Azijos valstybėmis) ${ }^{35}$. Tačiau egzistuoja vienintelis skirtumas. Buvusios Vidurio ir Rytų Europos valstybės dabar vẻl tampa laisvos rinkos ir liberalios demokratijos šalimis. Tai regionas, kur numatoma NATO plètra. Šis skirtumas suveda NATO plètrą su Amerikos globalizacijos modeliu ir jos vertybiniu matmeniu.

J. Kurtho nuomone, ,Amerikoje vis labiau suvokiama, kad Baltijos valstybès, per 10 metų padariusios milžinišką žingsnị demokratinės visuomenès link, įkūnija amerikietišką svajonę, kuri beveik niekur kitur pasaulyje per pastaruosius penkiasdešimt metų nesugebėjo prigyti““36. JAV politikai vis dažniau pabrèžia, kad demokratija yra garantija ir prieš terorizmą. Demokratinè santvarka stimuliuoja pakantumą kitoms idejjoms, tuo pačiu apsaugo visuomenę ne tik nuo terorizmo, bet ir nuo kitų ateities grèsmių. Lietuva, kaip ir kitos VR Europos valstybės, atsidūrè tų šalių tarpe, kurios po teroro aktų priartėjo prie Amerikos. Priartėjo ne fiziškai, bet psichologiškai, pasiūlydamos teroro aukoms ne tik moralinę, bet ir praktinę paramą. Dar daugiau - naujosios VR Europos šalių demokratijos pradejjo aktyviai skleisti demokratiją į kitus netoli nuo savęs nutolusius regionus. Jų specifinė patirtis, geresnis regiono specifikos žinojimas prisideda prie ,,amerikietiškų“vertybių plètros ir ịsitvirtinimo tokiuose regionuose kaip Ukraina, Kaukazas ar Balkanai.

Iki šiol JAV tikèjo demokratija Rusijoje, todèl stengèsi jokiu būdu neskatinti radikalių jègų ar kitaip pakenkti demokratizacijos procesui. İ NATO plètrą buvo

\footnotetext{
${ }^{35}$ Kurth J. „The Next NATO: Building an American Commonwealth of Nations“, The National Interest, Fall 2001, http://www.expandnato.org/kurthnato.html

${ }^{36}$ Ibidem.
} 
žiūrima per grèsmės Rusijos demokratijai prizmę. Dabar JAV iliuzijų liko daug mažiau. Pamatę, kad demokratija stipriausiai vystosi mažose VR Europos valstybėse, JAV stiprina savo pozicijas šiame regione. Kol kas tik Baltarusija lieka juoda dėme Europos demokratizavimo projekte, tačiau anksčiau ar vèliau demokratiniai pasikeitimai įvyks ir šioje šalyje. Todẻl laukiama, kad VR Europos regiono valstybės ypač Lenkija ir Lietuva prisidès prie Amerikos ir Europos valstybių pastangų demokratizuoti šią šalį.

JAV ypatingą reikšmę teikia Šiaurès šalių veiklai, diegiant demokratines vertybes tiek Europoje, tiek už jos ribų. Iš karto po Baltijos šalių nepriklausomybès atkūrimo, būtent Šiaurès šalys didžiulị dėmesį skyrè Lietuvos, Latvijos ir Estijos ekonomikos plètrai, struktūrinèms reformoms ir euroatlantinei integracijai. Tuo metu Šiaurès šalių reikšmė JAV politikoje smarkiai išaugo. Pastaruoju metu Šiaurès šalys, dalyvaujant ir Baltijos valstybėms, stiprina paramą kitiems regionams. Visų pirma nukreipiami didžiuliai resursai, kurie padeda vystytis Rusijos Šiaurẻs regionams. Tam tikslui naudojama Šiaurès iniciatyva ir ES Šiaurès matmuo.

Vertybiu plètros, demokratizacijos skatinimas kitose Europos dalyse ar už jos ribų ir ateityje išliks bendras VR ir Šiaurès Europos regioną ir JAV vienijantis reiškinys. Tai galimybė regionui prisidèti prie svarbaus JAV strateginio tikslo ịgyvendinimo ir taip JAV administracijoje užsitikrinti paramą savo vykdomai politikai.

\section{Pagalba, kovoje prieš terorizmą ir palaikant taiką pasaulyje}

JAV politikams teroristiniai aktai dar kartą patvirtino, kad karinis saugumo komponentas neprarado svarbos, siekiant garantuoti valstybės saugumą ir persekioti nusikaltėlius. Todèl dabar, kaip niekad anksčiau JAV reikalingi sajungininkai, kurie ginklais, pinigais ar žvalgybine informacija gali prisidèti prie karinių operacijų. Tokia pagalba daugumai VR Europos valstybių tapo raktu ị NATO.

JAV rekomenduoja NATO valstybėms ir kandidatèms kurti modernias ir efektyvias karines pajègas. JAV teikia gana didelę pagalbą VR Europos regiono šalims. Po Izraelio, Egipto ir Jordanijos, VR Europos regionas yra antras svarbiausias JAV karinės pagalbos gavėjas. JAV administracija tikisi ir žino, kad šios valstybes ateityje galès prisidèti prie JAV vykdomų karinių misijų. 


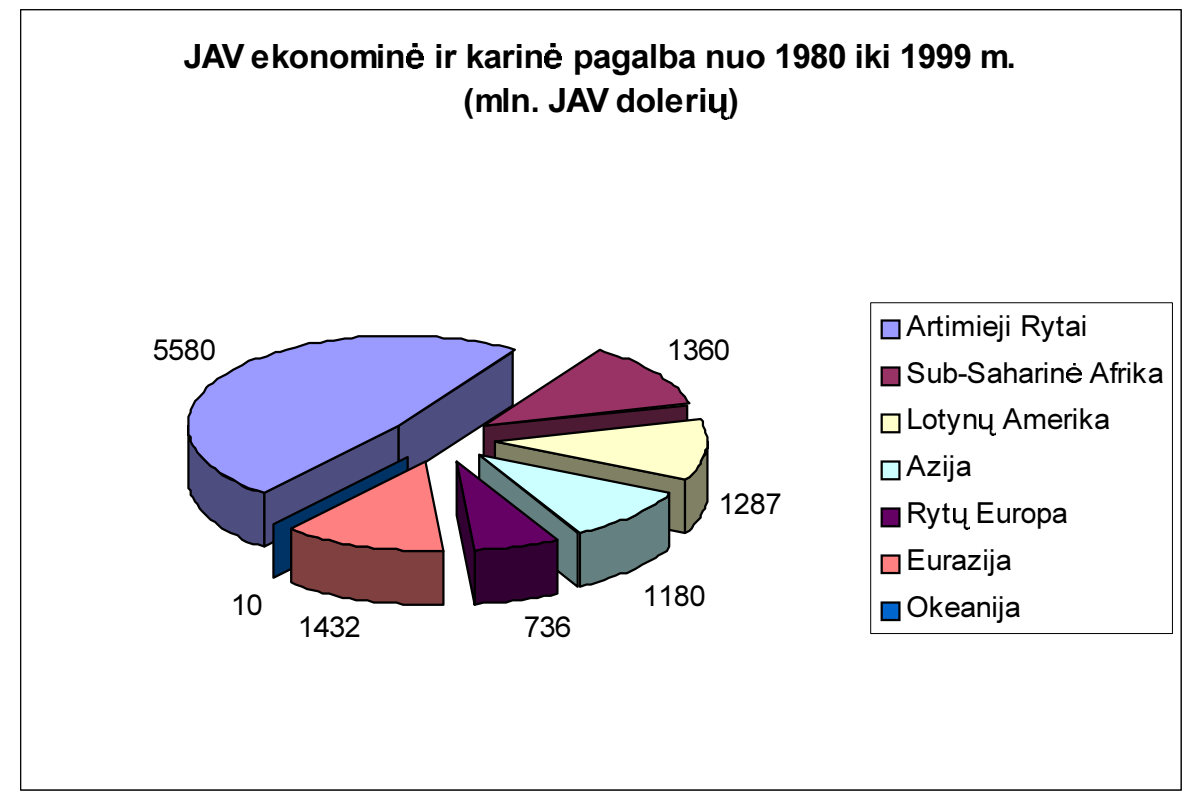

U.S. Census Bureau, Statistical Abstract of the United States, 2001, 797.

JAV vertinama sajungininkų ir partnerių pagalba, suteikta operacijos Afganistane metu (oro erdvè, oro uostai, specialiosios pajëgos, ekonominès priemonès). Ypatingai NATO kandidatès yra skatinamos kurti karinius vienetus, sąveikius su NATO pajègomis. Tai reiškia, kad ateityje jų dalyvavimas bendrose karinėse operacijose turi potencialą augti. Dar svarbesnè yra partnerių kontribucija taikos palaikymo operacijose. Visos šalys, siekiančios narystès NATO, turi išskleidę gana didelius pajègumus Balkanuose, kitos valstybès dar turi pajègas dislokuotas kitose pasaulio dalyse. Tai leidžia JAV perdislokuoti savo karius ir panaudoti juos kitose operacijose.

Taigi nors regionas ir neturi karinių pajègumų, galinčiu paveikti pasaulinę karinę pusiausvyrą, aktyvus VR ir Šiaurès Europos šalių dalyvavimas antiteroristinėje kampanijoje ir taikos operacijose prisideda prie JAV politikos igyvendinimo kitose pasaulio dalyse. Nors VR ir Šiaurès Europos regionas antiteroristinejje kampanijoje nėra savarankiškas veikèjas, tačiau jis yra naudingas JAV, kaip globalinės strategijos rèmëjas.

\section{Geostrateginè pusiausvyra Europoje}

JAV interesų požiūriu VR ir Šiaurès Europa yra svarbi kaip Europos dalis. Tai regionas, kuris veikia kontinente vykstančius procesus bei dalyvauja priimant sprendimus ES viduje, kurie ateityje veiks globalu galios balansą. Europos politika svarbiausia VR ir Šiaurès Europos ir JAV bendradarbiavimo arena. Būtent Europos kontinente JAV su VR ir Šiaurès Europos regionais sieja bendri ir svarbūs saugumo interesai - išlaikyti transatlantinị ryšși, neleisti kurti atskiru nuo NATO europinių pajègų, demokratizuoti Rusiją, neleisti Europoje dominuoti vienai valstybei.

Bendradarbiauti skatina ir tai, kad būsimos ES narès iš VR Europos yra labiau proamerikietiškai nusiteikusios, palyginus su italais, prancūzais ar vokiečiais, 
kurie nejaučia didelio seno tipo karinių grèsmių pavojaus. JAV Užsienio politikos analizės instituto Baltojoje knygoje Strategic and Operational Implications of NATO Enlargement in the Baltic Region daroma išvada, kad „Baltijos valstybès, kaip ir kitos VR Europos šalys, priklauso taip vadinamiesiems „,naujiesiems atlantistams“, kurie nori išlaikyti JAV Europoje ir nenori, kad NATO taptų ESBO tipo organizacija“"37.

Ypatingai VR Europos valstybès, besiribojančios su vis dar nestabilia NVS erdve, siekia JAV saugumo garantijų, kadangi Europos Sajunga dèl savo karinio nepajëgumo joms nèra saugumo alternatyva. JAV supranta, kad Lietuva, kuri ribojasi su smarkiai militarizuotu Kaliningrado kraštu ir autoritarine Baltarusija, net ir tapusi Europos Sajungos nare, savo saugumo politika pirmiausia derins su JAV. Tai leistų amerikiečiams per VR ir Šiaurès Europos šalis veikti Europos Sajungos sprendimų priëmimo procesą ir taip ginti savo nacionalinius interesus. Iš Šiaurès šalių tokị vaidmeni jau keletą dešimtmečiu vaidina Danija, kuri netapo Vakarų Europos Sajungos nare, o veliau išsiderẻjo tam tikras išimtis Mastrichto sutarties ES Bendros užsienio ir saugumo politikos nuostatoms.

Siekdamos saugumo, VR Europos šalys automatiškai tampa didesnemis JAV gerbëjomis nei tarkime Vokietija ar Prancūzija. Todèl plèsdama NATO ị rytus per būsimas ir esamas ES nares, JAV išlaiko ir netgi ateityje galès padidinti savo įtaką išplèstoje Europoje Sajungoje. Kennethas N. Waltzas straipsnyje „The Balance of Power and NATO Expansion“ situaciją apibūdino taip: „Akivaizdu, kad NATO pletra yra būdas JAV išlaikyti savo ranką ant ES užsienio ir gynybos politikos ${ }^{38}$ “. Dél sékmingos VR Europos šalių integracijos į ES, NATO plètra tapo vienu iš respublikonų administracijos prioritetu.

Duodama karines saugumo garantijas, JAV užsitikrina, kad šios šalys neskubins ES karinių pajègų kūrimo, kurios ateityje leistų ES konkuruoti su JAV globalinèje arenoje. Sẻkmingai integravusios į NATO, VR Europos šalys greičiausiai taps patikimomis sąjungininkėmis, suinteresuotomis stiprinti NATO struktūrą, o ne ją silpninti, teikiant prioritetą ES kuriamai karinei struktūrai. Tuo pačiu VR Europos valstybès, tik neseniai išsivadavusios iš buvusios SSRS diktato, labai ịtariai žiūri i galimus suvereniteto apribojimus, kurie kiltu po ES narystès. Akivaizdu, kad po narystės šioje organizacijoje VR Europos šalys daugelyje sferų stabdys integraciją, ypač karinejje srityje. Vašingtonas niekada neskatino Europos susivienyti ir jam visada bus geriau kalbèti su atskiromis valstybėmis nei su stipria jų grupe. JAV gali sau leisti saugumo prasme padalyti Europą su potencialiais konfrontacijos elementais siekdama, kad tokia Aljansu besiremianti Europa liktų priklausoma nuo Vašingtono. L. Wallino nuomone, ne veltui ES politika kandidačių atžvilgiu yra vienareikšmiška - tapdamos narėmis jos turès prisiimti visus narystès įsipareigojimus, t.y. netgi tuos, dèl kurių kitos ES šalys kaip Danija ar Didžioji Britanija sugebejo išsikovoti tam tikrų išimčių $u^{39}$. Jų narystė ES visiškai atitinka JAV didžiosios strategijos interesus laikyti iš dalies fragmentuotą Europą, kuri būtų JAV partneriu, bet ne konkurentu tarptautineje arenoje.

\footnotetext{
${ }^{37}$ Institute for Foreign Policy (IFPA) Analysis Strategic and Operational Implications of NATO Enlargement in the Baltic Region, 2002, 1.

${ }^{38}$ Waltz (note 14).

${ }^{39}$ Pavyzdžiui, tik tada, kai Danijai buvo suteiktos keturios išimtys dẻl bendros valiutos, gynybos, policijos ir teismu bendradarbiavimo bei dèl Europos pilietybès, danai per antrajị referendumą 1993 metais pritare Mastrichto sutarčiai. Žr.: The European Documentation Centre (EDC) at the University of Mannheim Protocol On Denmark The High Contracting Parties, Desiring To Settle Certain Particular Problems Relating To Denmark, http://www.uni-mannheim.de/users/ddz/edz/ doku/vertrag/engl/m_proto.htm
} 
Šiaurès Europos valstybès taip pat nėra ES „sukarinimo“ šalininkès. Šiauriečiai siekia stiprinti ES civilinị krizių valdymo komponentą, o ne kurti naują karinę mašiną. Tokia jų politika visiškai atitinka JAV interesus Europoje, ir susilauks visapusiško JAV palaikymo.

NATO plètra ir saugumo garantijos vidurio europiečiams sprendžia JAV dar vieną globalinès politikos uždavini - sutrukdyti ateityje susikurti Europos ir Rusijos aljansui. Pagal A. Utkiną, Baltijos valstybės „kartu su Lenkija, neapsisprendusia Ukraina, Rumunijos pusėn žiūrinčia Moldova, vietoj transparentiško koridoriaus tapo savotišku pleištu tarp Vakarų, JAV ir Rusijos. Baltijos valstybių integracija į vakarietiškas struktūras padare jas JAV ir Rusijos nesutarimų zona“"40.

Antiteroristinès kampanijos metu, JAV suartejjus su Rusija, šių nesutarimu reikšmė smarkiai sumažèjo. Abiejų valstybių dėmesiui nukrypus į pietus, Baltijos šalys prarado konfrontacijos zonos statusą. Jos tapo laisvos ir demokratinès Europos dalimi. Baltijos šalių prièmimas ị NATO - tik viena iš Europos konsolidacijos proceso dalių, proceso, kuris ateityje apims ir kitas valstybes. Vašingtone supranta, kad Lietuvos, Latvijos ir Estijos naryste privers Švediją ir Suomiją peržiūrèti savo saugumo politiką ir galbūt ateityje prisijungti prie aljanso, tuo būdu sustiprinti regiono saugumą ir integruoti ją po JAV vadovaujamos NATO skéčiu.

D. Gorenburgo nuomone, , NATO plètra privers Švediją ir Suomiją prisijungti prie NATO. Šios šalys turètų smarkiai sustiprinti NATO pajęgumus tiek regiono viduje, tiek už jo ribų. Jų ịstojimas Baltijos jūrą paverstų vidine NATO jūra. Tai reiškia, kad Šiaurès Europoje susidarytų saugumo bendruomenė, kur klesti bendradarbiavimas tarp NATO ir ES valstybių, kur Rusija nejaučia grèsmės savo saugumui, o Lietuva, Latvija ir Estija grịžta ị Vakarų glébị ‘“41 .

Proamerikietiška Šiaurès Europa (ypač jei ị ją žiūrètume kaip ị platesnį regioną, apimantį ir Didžiają Britaniją) JAV strategijoje vaidina ir kitą svarbų vaidmenį Europos Sajungoje ji išbalansuoja kitus galios centrus, kurie grèstų amerikiečių interesams - vokiškaji ir prancūziškajji. Ekonomiškai išsivystęs Šiaurès Europos regionas ypatingai svarbus kaip atsvara Vokietijos dominavimui Europos Sajungoje. Mažos ir gana panašios bei gerus bendradarbiavimo mechanizmus sukūrusios Šiaurès šalys sudarytų gana vientisą bloką ES viduje. Šiaurès blokas, apimant ir Baltijos šalis, išplèstoje ES Taryboje pagal Nicos sutartị turès 39 balsus, tai yra truputį daugiau nei 12 procentų visų Tarybos balsų. ${ }^{42}$ Jeigu pridètume Lenkiją ir Didžiają Britaniją, kitas dvi platesnio Baltijos jūros regiono valstybes, regiono balsų skaičius išaugtų iki 95 ir igautų organizacijoje veto teisę.

Panaši situacija Europos Sajungoje susiklostys ir su VR Europos šaliu grupe. Po pirmojo ES plètros etapo ES Taryboje jos kontroliuos 77 balsus, tai yra iki blokuojančios mažumos trūks tik 8 balsų. Po 2007 m., prièmus Rumuniją ir Bulgariją, regiono ịtaka dar labiau padidès. Su 101 balsu šalys galès stabdyti visus pagrindinius ES sprendimus. Taigi jei regiono valstybės sėkmingai koordinuos savo pastangas, jų įtaka Europoje tik didès, o tai veiks ir santykius su Vašingtonu.

${ }^{40} \mathrm{y}_{\text {TКин (note 6). }}$

${ }^{41}$ Gorenburg D., etc. The Expansion of NATO into the Baltic Sea Region: Prague 2002 and Beyond.

CNA Corp., Centre for Strategic Studies, 2002, 2.

42 „Treaty of Nice“ Official Journal of the European Communities, 103 2001, C 80/1. 


\section{Ekonominis bendradarbiavimas}

Ekonomiškai VR bei Šiaurès Europos ir JAV priklausomybė yra ganėtinai maža. Prekybos apimtys nedidelès, Šiaurės Europa užima mažiau nei 2 procentus visos JAV prekybos dalies, o VR Europa - tik 0,42 procento. Nors prekybos mastai turi tendencijų augti, o VR Europos šalių atveju per dešimtmeti jų dalis išaugo dvigubai, JAV politikai tai neturès didesnès įtakos.

\section{VR ir Šiaurès Europos regiono dalis bendroje JAV užsienio prekyboje}

\begin{tabular}{lcccccccc}
\hline & 1993 & 1994 & 1995 & 1996 & 1997 & 1998 & 1999 & 2000 \\
\hline $\begin{array}{l}\text { N5 (Śiaurès } \\
\text { salys) }\end{array}$ & 1,60 & 1,53 & 1,59 & 1,68 & 1,69 & 1,54 & 1,63 & 1,63 \\
$\begin{array}{l}\text { B3 (Baltijos } \\
\text { salys) }\end{array}$ & 0,02 & 0,03 & 0,03 & 0,03 & 0,04 & 0,04 & 0,05 & 0,08 \\
VR Europa & 0,25 & 0,27 & 0,26 & 0,26 & 0,30 & 0,34 & 0,37 & 0,42 \\
NB8 (N5+B3) & 1,62 & 1,55 & 1,62 & 1,72 & 1,73 & 1,58 & 1,68 & 1,71 \\
N5 + VRE & 1,85 & 1,80 & 1,85 & 1,94 & 1,99 & 1,88 & 2,00 & 2,05 \\
\hline
\end{tabular}

U.S. Census Bureau, Statistical Abstract of the United States, 2001, 802-805.

Atskiru bendradarbiavimo punktu lieka gynybos pramonès sritis. Technologinis skirtumas tarp Europos ir JAV kol kas nemažeja, o amerikiečiams daug investuojant ị naujas technologijas turètų tik didèti. JAV pramonè turi didelį norą įsitvirtinti Vidurio ir Rytų Europos rinkose, o NATO narystė bei su ja susiję įsipareigojimai - tureti modernias ir efektyvias pajègas - skatina šalis issigyti modernią ginkluotę. Naujų NATO narių ir kandidačių išlaidos gynybai pasiekẻ beveik 9,3 mlr. JAV dolerių ir turi tendenciją augti.

\begin{tabular}{|lrrrr}
\hline & \multicolumn{4}{c|}{ Gynybos išlaidos } \\
\cline { 2 - 5 } Valstybé & \multicolumn{4}{c|}{ (mln. JAV doleriu $)$} \\
\cline { 2 - 5 } & 1997 & 1998 & 1999 & 2000 \\
Čekija & 987 & 1.132 & 1.155 & 1.133 \\
Vengrija & 666 & 647 & 768 & 777 \\
Slovakija & 414 & 407 & 305 & 340 \\
Slovénija & 329 & 360 & 337 & 223 \\
Lenkija & 3.073 & 3.356 & 3.222 & 3.191 \\
Lietuva & 135 & 134 & 107 & 195 \\
Latvija & 156 & 157 & 58 & 70 \\
Estija & 65 & 68 & 71 & 79 \\
Bulgarija & 339 & 390 & 392 & 347 \\
Rumunija & 793 & 870 & 607 & 809 \\
Albanija & 94 & 98 & 140 & 111 \\
Makedonija & 132 & 136 & 67 & 76 \\
Iš viso: & 9180 & 9753 & 9228 & 9351 \\
\hline
\end{tabular}

Wilk A. The new members of the new NATO, http://www.osw.waw.pl/en/epub/eRap2002/ecz_01.htm, table 3 . 
Tiesa, iki šiol saugumo poreikiai ir vis didesnis gynybos bendradarbiavimas negarantavo, kad didelè dalis JAV gynybos pramonès produkcijos dalis keliaus ị šalis, kurios neseniai tapo ar ateityje taps naujomis NATO naremmis. Čekija pora metų negali apsispręsti dèl lèktuvų pirkimo kontrakto - tiek JAV, tiek Europos vyriausybès naudoja politinị spaudimą ir siūlo pirkti savo pramonès produkciją. Norẻdama įsigyti prieštankinę ginkluotę, Lenkija sudarè antrą pagal dydį kontraktą su Izraelio kompanija, kuri gamina Spike sistemas.

Lietuva VR Europos regione įsigijo bene daugiausia JAV gynybos pramonès produkcijos. Lietuva įsigijo taktinio ryšio priemonių iš Harris Corp., prieštankines Javelin sistemas iš Lockheed Martin ir Reytheon Corp. bei pasirašè kontraktą įsigyti JAV bendroviu „Hughes Missile System Company“ ir „General Dynamics / Raytheon Corp. "gaminamų priešlektuvinių raketinių sistemų Stinger ${ }^{43}$. Tai atitinka ir Lietuvos interesus, kadangi investuodama į amerikietišką produkcija Lietuva perka ne tik produktą, bet ir didesnį JAV susidomejimą savo regionu ir valstybe.

\section{Lietuvos ir Baltijos šalių vieta globalinèje JAV strategijoje}

JAV ir VR ir Šiaurès Europą sieja bendras saugumo ryšys, bendros vertybės ir bendras grèsmių supratimas. Ekonominiu požiūriu šalių tarpusavio priklausomybẻ ir prekybos srautai yra gana maži. Šie faktoriai diktuoja JAV darbotvarkę regione, kurioje dominuoja ne ekonominès, o regioninio stabilumo, NATO plètros, santykių su Rusija temos.

JAV strategija Lietuvos atžvilgiu atspindi bendrą JAV užsienio politikos strategiją tiek Europos, tiek VR ir Šiaurès Europos šalių atžvilgiu. JAV interesai Lietuvoje yra atspindys platesnių JAV užsienio politikos tikslų, tokių kaip regioninio saugumo skatinimas, kova prieš terorizmą, užsienio investicijų skatinimas, ekonominių reformų ir laisvos prekybos kèlimas, kova prieš nusikalstamumą ir korupciją.

JAV ypatingą dèmesį taip pat skiria tokiems vidaus politikos reikalams, kaip turto grąžinimas žydams, demokratizacija, privatizacija, požiūris į tautines mažumas ir t.t. JAV taip pat svarbu kaip Lietuvos užsienio politika sugeba paremti JAV užsienio politikos tikslus, t.y. stiprinti JAV-Europos santykius, prisidèti prie kovos su terorizmu, dalyvauti NATO misijose, gerinti santykius su Rusija ar prisidèti prie amerikietiškų vertybių plètros.

Geopolitiškai Lietuva, kaip ir kitos regiono šalys, nèra prioritetinis regionas JAV didžiojoje strategijoje. VR ir Śiaurès Europa nevaidina svarbaus vaidmens kovoje prieš terorizmą, jos teritorijose nèra strateginių žaliavų resursų (naftos, gamtinių dujų, nikelio ar pan.) išteklių, jos teritorijoje nèra svarbių komunikacijų linijų, ji geografiškai nekontroliuoja svarbių sąsiaurių ar prièjimo prie strategiškai svarbių regionų, o prekybos apimtys sudaro mažą dali JAV bendros užsienio prekybos.

Vis dèlto šis tylus ir ganètinai turtingas pasaulio užkampis turi tam tikrų savybių, kurios svarbios JAV strategijos iggyvendinimui, ypatingai igyvendinant JAV interesus Europos kontinente daugiau regioniniu, o ne globaliniu lygmeniu. Europa ateityje išliks svarbiausiu JAV užsienio politikos objektu, todèl Lietuva ir jos regiono valstybės didžiausią reikšmę turès bendrame Europos kontekste.

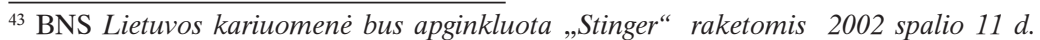


Lenteleje pavaizduota, kuriais aspektais tiek VR, tiek Šiaurès Europos šalys gali prisideti prie JAV strategijos igyvendinimo:

\begin{tabular}{|c|c|c|c|}
\hline & $\begin{array}{c}\text { VR } \\
\text { Europa }\end{array}$ & $\begin{array}{l}\text { Šiaurès } \\
\text { Europa }\end{array}$ & $\begin{array}{c}\text { Baltijos } \\
\text { šalys }\end{array}$ \\
\hline \multicolumn{4}{|l|}{ Vertybinè dimensija } \\
\hline Rytų Europos demokratizacija & + & + & + \\
\hline $\begin{array}{l}\text { Saugumo eksportavimas i } \\
\text { tolimesnius regionus }\end{array}$ & $+/-$ & + & $+/-$ \\
\hline \multicolumn{4}{|l|}{ Praktiniai pajègumai } \\
\hline Galios projektavimas & - & - & - \\
\hline Antiterorizmas & $+/-$ & $+/-$ & $+/-$ \\
\hline Taikos palaikymo operacijos & + & + & + \\
\hline \multicolumn{4}{|l|}{ Strateginis balansas } \\
\hline Stiprinti transatlantinị ryši & + & + & + \\
\hline $\begin{array}{l}\text { Neleisti susiformuoti ne NATO } \\
\text { kariniam ES matmeniui }\end{array}$ & + & + & + \\
\hline Atsvara Vokietijai ES viduje & - & + & $+/-$ \\
\hline Silpninti ES politinę integraciją & + & + & + \\
\hline $\begin{array}{l}\text { Neleisti atgimti Rusijos } \\
\text { ekspansionizmui }\end{array}$ & + & - & + \\
\hline \multicolumn{4}{|l|}{ Ekonominiai ryšiai } \\
\hline Prekyba & - & - & - \\
\hline Gynybos pramonè & $+/-$ & + & + \\
\hline
\end{tabular}

Noreddama išlaikyti JAV susidomėjimą, Lietuva, kartu su kitomis Baltijos valstybėmis, privalo rasti sritis, kur jų indẻlis turètų reikšmę amerikiečiams. Keli aspektai yra ypatingai svarbūs:

- kaip būsima ES narè, kuri kartu su savo kaimynais turès įtakos ES sprendimams. Kuo ši įtaka bus didesnè, tuo svarbesnè Lietuva bus Vašingtone; - kaip JAV eurazijinės politikos rèmejja, kartu su kitomis regiono valstybėmis prisidedanti prie amerikietiškų vertybių sklaidos bei karo su terorizmu.

\section{JAV ịsitraukimo ị regioną nauda ir kaštai}

VR ir Šiaurès Europos šalys, norèdamos užtikrinti amerikiečių buvimą regione, tam turi sudaryti palankias sąlygas. JAV dalyvavimo regione aktyvumas yra numatomų kaštų ir gaunamos naudos išvestine. Kadangi Lietuva nori matyti amerikiečius aktyviai veikiančius regione, ji turi tiek politine, tiek ekonomine, tiek karine prasme sudaryti sąlygas jų veiklai savo šalyje.

Siekis turèti JAV Lietuvoje kyla iš mūsų šalies geopolitinių realijų. Per paskutinị šimtmetį Lietuvos šansai išlikti nepriklausoma valstybe tiesiogiai priklausè nuo Rusijos ekspansionizmo. Dèl šios istorinès patirties Lietuvos lyderiai jautriai reaguoja ị bet kokius Rusijos politikos pokyčius. Po Šaltojo karo pabaigos Rusijos rolè pasaulyje smarkiai pasikeitè, Maskva prarado didžiosios galybès statusą, tai pokytis, kuris atnešè didelę naudą Lietuvai. Tuo pačiu imperinès nuotaikos nesumažèjo, sumažejo tik galimybès ịgyvendinti savo ambicingus planus. Rusijos atsitraukimas nuo pozicijų, kurios įvardijamos kaip gyvybiniai interesai, yra susijęs su noru koncentruotis į valstybès vidinę konsolidaciją ir ekonominę reformą. 
NATO ir ES narystė reiškia, kad Baltijos šalys yra išimamos neribotam laikui iš Rusijos ekspansionistinių planų. Tačiau visiškas pasitraukimas iš Rusijos orbitos yra sunkiai įmanomas visų pirma dèl Maskvos turimų ekonominių svertų. Pastarieji dar padidès, kai Maskva ir toliau sèkmingai plès savo strateginę partnerystę su ES energetikos srityje bei turès didelès įtakos ES šalių energetikos sektoriui.

Rusija išlaiko savo interesus Lietuvoje, tik priemonès, kurių pagalba jų bus siekiama, daugiausia bus ekonominès. Vienas iš skaudžiausių spaudimo būdų Lietuvai būtų ekonominis šantažas, kuriuo siekiama veikti sprendimų prièmimo procesą. $^{44}$ ES naryste garantuoja tam tikrą apsaugą nuo panašių poveikio priemonių, tačiau nesprendžia pagrindinès Lietuvos geopolitinès dilemos. Kol Lietuva yra tik dviejų geopolitinių vektorių (ES-Vokietijos ir Rusijos) sankirtoje, regionas liks geopolitinès įtampos zona bei atspindès šių dviejų galios centrų tarpusavio santykius. Lietuvai, kaip ir kitoms regiono valstybėms, reikalingas trečias vektorius regione. Jis minimizuotų pirmų dviejų kuriamą įtampą ir regiono valstybėms suteiktų didesnę veiksmo laisvę bei galimybę balansuoti savo politiką jų atžvilgiu. Tokiu trečiu vektoriumi gali būti tik JAV. Dèl regiono reikšmès Europos galios balansui, JAV irgi nori, kad Baltijos regionas, kur jaučiama skirtingų geopolitinių jẻgų įtaka, netaptų nestabilus ateityje. NATO naryste ir saugumo garantijos Baltijos šalims garantuoja, kad ateityje Baltijos valstybės galės geriau atsilaikyti prieš Rusijos bandymą didinti savo ịtaką, panaudojant tokius svertus, kaip žaidimas etnine korta ar energetiniais ištekliais ${ }^{45}$. NATO plètra ir JAV įsigalëjimas Baltijos valstybèse - tai kartu ir ženklas Rusijai, kad Šaltojo karo laikais nubrěžtos įtakos zonos regione yra perbraižytos taip, kaip nori amerikiečiai, o VR ir Šiaurès Europoje JAV užima dominuojančią poziciją.

JAV aktyvumas regione reiškia tam tikrus ịsitraukimo kaštus, kurie yra neišvengiami, kuriant stabilumą regione, neseniai buvusiam geopolitinès konfrontacijos zona. JAV įsipareigojimai -ilgo, dešimtmetį trukusio proceso pasekmè. L. Wallinas studijoje apie NATO plètros pasekmes Švedijai rašo, kad 90-ujų metų viduryje britai ir vokiečiai siūlè, kad Švedija ir Suomija prisiimtų atsakomybę už Baltijos valstybių saugumą, bet skandinavai neturéjo nei noro, nei galimybių tai padaryti. JAV vis daugiau nerimavo, kad Baltijos valstybės tampa pilkaja zona, o tai galètų turèti neigiamos įtakos visam Europos saugumui. ${ }^{46}$ Ypač aiškiai tai buvo aprašyta RAND studijoje NATO Enlargement and the Baltic states. ${ }^{47}$ Jos analize ir rekomendacijos skatino aktyvesnę JAV politiką Baltijos jūros regione. Rezultatas - Baltijos chartija, kur JAV pažadèjo didesni aktyvumą regione, o Baltijos valstybès - laukti kito NATO plètros etapo. Nors Chartija ir skelbė, kad Amerika turi „,real, profound and enduring“ interesą mūsų regione ${ }^{48}$ tačiau tuo pačiu metu ji buvo daugiau JAV administracijos kompensacija už nepakvietimą į NATO, nei realus ịsipareigojimas Baltijos šalims.

\footnotetext{
${ }^{44}$ Tokios politikos pavyzdi jau turime. Ekonominè blokada $1991 \mathrm{~m}$. privertė Lietuvos parlamentą priimti deklaraciją dèl nepriklausomybès atstatymo moratoriumo.

${ }^{45}$ Institute for Foreign Policy Analysis (note 37), 2.

${ }^{46}$ Wallin L. NATO Enlargement in the Baltic Sea Area - Possible Consequences for Sweden, The TESLA Group, Swedish Defence Research Agency, 2002.

${ }^{47}$ Asmus R., Nurick R. „NATO Enlargement and the Baltic States“, Survival, Vol.38, N 2, 1996, 121-142.

${ }^{48}$ Charter of Partnership Among The United States of America and the Republic of Estonia, Republic of Latvia, and Republic of Lithuania. http://www.usemb.ee/charter1.php3, žiūrèta 20021029.
} 
Priežasčių, dèl kurių JAV nenorėjo suteikti Baltijos šalims saugumo garantijų buvo keletas. Pirma, nebuvo didelio strateginio intereso. Jeigu Lenkija buvo suprantama kaip esminė (vital) šalis Vakarų saugumui, tai dèl ịvairių priežasčių Baltijos šalyse Vakarai nematė strateginio intereso. R. Asmuso bei R. Nuricko nuomone, Baltijos šalys nebuvo pakviestos į pirmaji NATO plètros etapą, nes jos neturi pakankamai politinès paramos aljanse. Net ir JAV, kur Baltijos šalims jaučiama didelè simpatija, parama jų narystei buvo gana ribota. Tačiau Baltijos šalims labiausiai trūko stipriausių Europos valstybių - Vokietijos, Prancūzijos ir Didžiosios Britanijos ịsipareigojimų ${ }^{49}$ İ klausimą, ar eitų kovoti dèl Baltijos šalių, siekiant apginti jas nuo išorinès agresijos, paprastai buvo neatsakoma arba atsakoma neigiamai. Dauguma Amerikos analitikų ir politikų sutiko, kad „JAV neturi svarbių strateginių ar ekonominių interesų Baltijos šalyse, ir nė viena iš šių valstybių nèra verta, kad JAV prisiimtų strateginius pavojus ir kaštus, susijusius su JAV įsipareigojimais toms šalims “ ${ }^{\text {50 }}$.

Dar 2001 m. pradžioje daugelyje šalių vyravo įsitikinimas, kad Lietuva nebus pakviesta ị antraji NATO plètros etapą. Štai $2001 \mathrm{~m}$. balandžio 30 d. įtakingas JAV strateginių studijų centras „Stratfor“" paskelbè analizę skambiu pavadinimu „Baltic States membership in NATO unlikely“. „Stratfor“ nuomone, ,,apginti ir siųsti pastiprinimą i Baltijos šalis yra sunku dẻl ilgos fronto linijos, mažo gynybos gylio ir ribotu galimybių, kurios leistų turèti geras komunikacijas karo metu. Konflikto atveju dèl Rusijos noro bet kuriomis priemonėmis apginti Kaliningrado sritị ir jame esančius uostus, Baltijos šalims reikès pastiprinimų iš aljanso teritorijos. NATO turès siųsti pagalbą sausuma, kadangi dislokuota Kaliningrade Rusijos kariuomene neleis to daryti oro ar jūrų keliu. Sausumos kelių infrastruktūra, sukurta Maskvos valdymo metais, yra palankesnè Rusijai. Sunkumai permesti pastiprinimus ị Baltijos šalis leis Rusijai lengvai juos neutralizuoti, paliekant NATO karius laukti pagalbos kur nors ant Baltijos jūros kranto"s1.

$2002 \mathrm{~m}$. JAV ir kitos aljanso narès nusprendè, kad vis dèlto verta suteikti Baltijos šalims saugumo garantijas. Pasirodè, kad amerikiečiai yra pasiryžę aukoti dalị savo išteklių šių anksčiau vadinamų neapginamu šalių gynybai. Šis istorinis pasikeitimas gerai atspindi sumažéjusius ịtraukimo ị mūsų regioną ir saugumo garantijų suteikimo kaštus bei, kas svarbiausia, - padidejusįi interesą regionu.

Vienas svarbiausių veiksnių, prisidèjusių prie paramos Baltijos šalims didejjimo, buvo po rugsėjo $11 \mathrm{~d}$. teroristinių išpuolių sustiprèjusi vertybių reikšmė JAV užsienio politikoje. J. Kurtho žodžiais, „po dešimties metų herojiškos kovos už nepriklausomybę Baltijos šalys nepaprastai sèkmingai ịgyvendina Amerikos propaguojamas liberalios ekonomikos, laisvos rinkos ir teisinès valstybės idėjas. Jei šiuo požiūriu yra šalių, nusipelniusių būti pakviestomis ị NATO, tai Baltijos šalys privalo būti tarp jų “'52 .

Toks vertybinis matmuo kartu su VR Europos šalių ekonomine plètra, sẻkmingomis derybomis dèl narystės ES, demokratizacijos procesu ir rinkos ekonomikos stiprinimu skatino JAV didesnį susidomèjimą ir supratimą, kad šis proamerikietiškas regionas gali būti naudojamas, siekiant globalinių JAV tikslų. Jei seniau šių

\footnotetext{
${ }^{49}$ Asmus, Nurick (note 47), 124.

${ }^{50}$ Kurth (note 35).

${ }^{51}$ Strategic Forecasting Baltic States Membership in NATO Unlikely, Global Intelligence Update, žiūrèta 200104 27, http://www.stratfor.com

${ }^{52}$ Kurth (note 35 ).
} 
šalių vieta JAV strategijoje buvo iš dalies sprendžiama sentimentų ar istorinės tiesos atstatymo argumentais, tai dabar JAV politikos pagrindą sudaro siekis išnaudoti regiono geostrateginę vertę bei jos teikiamus pranašumus ir įtvirtinti JAV dominavimą Europoje.

Tuo pačiu Rusijos-JAV santykių pokyčiai, didejjantys regiono valstybių gynybos biudžetai, gynybos pajėgų transformacija reiškia mažesnius JAV kaštus, igyvendinant savo politiką regione. Po V. Putino atėjimo ị valdžią įvyko Rusijos pasisukimas ị Vakarus. Nauja Rusijos užsienio politika ir strateginė Maskvos-Vašingtono partnerystė Vakaruose sumažino konfrontacijos su Rusija baimę, kuri kilo dèl Baltijos šalių narystès NATO. Naudodamasi tokiomis palankiomis aplinkybėmis, JAV nusprendè įtvirtinti savo dominavimą ir suteikè regiono valstybėms saugumo garantijas.

JAV besikeičiantị požiūrị i Lietuvos integraciją geriausiai iliustruoja amerikiečiu kariškių duodamos rekomendacijos Lietuvos kariuomenei. JAV gynybos ir valstybés departamentų ekspertų grupé, vadovaujama gen. mjr. Kievenaaras, 1997 m. pabaigoje 1998 m. pradžioje atliko Lietuvos ginkluotujų pajęgų icertinimąa $a^{53}$, kurio tikslas yra padèti išvystyti nacionalinę gynybos strategiją, atsižvelgiant į grèsmes bei turimus resursus, ir numatyti ginkluotųjų pajègų plètros perspektyvas. Lietuvos prašymu, panaši studija buvo pakartota $2001 \mathrm{~m}$. pabaigoje ir išleista JAV Gynybos departamento vardu ${ }^{54}$.

Lyginamoji abiejų studijų analizė akivaizdžiai rodo pasikeitusi JAV požiūrị i Lietuvos kariuomenę ir pajègumus, kuriuos JAV norètų matyti Lietuvos gynybos sistemoje. Pirmoje studijoje aiškiai ir nedviprasmiškai išreičkiamas pritarimas teritorinès gynybos modeliui, pagal kuri tuo metu buvo kuriama Lietuvos kariuomenè. Studija nedaug skyrè dėmesio Lietuvos galimybėms skirti pajėgų tarptautinėms ir Vašingtono sutarties 5 str. operacijoms bei galimybei krizès Lietuvoje metu priimti sajungininkų pagalbą. JAV pagrindinè rekomendacija aiški - Lietuva turi skirti išteklius nacionalinių savigynos pajègumų plètrai, kariuomenè turi būti pasirengusi gintis pati, be sajungininku pagalbos.

2001 m. studijoje JAV požiūris iš esmès pasikeitè. Amerikiečiai nagrinėja tai, ką Lietuva gali pasiūlyti JAV ir NATO, kokie pajègumai ir infrastruktūra gali būti panaudota sajungininkų tikslams. Didžiulis dèmesys skiriamas C3I (angl. command, control, communications, intelligence), suderinamumui su NATO, anglų kalbos žinojimui, pasiruošimui priimti partnerių pajẻgas, didesnį dèmesị skiriant Šiaulių oro ir Klaipedos jūrų uostui. Tiek studijoje, tiek konsultacijų metu amerikiečiai faktiškai nebeminimi teritorinès gynybos modelio. Skatinamos rengti sąveikios su NATO pajëgos, abejojama didelių ir nemobilių pajëgų reikalingumu.

Taigi JAV pradèjo rimtai žiūrèti į Lietuvą, kaip į būsimą sajungininkę, valstybę, kuri reikiamu momentu praktiškai galètų prisidèti prie amerikiečių vadovaujamų misijų ir operacijų. Rekomendacija nebenaudoti teritorinio gynybos modelio ir skirti didesnį dèmesį sajungininkų pajègų prièmimui akivaizdžiai demonstruoja, kad konflikto metu Lietuva nekovos viena ir galès remtis sajungininkų pagalba. Tiesa, konkretaus pagalbos plano nei amerikiečiai, nei NATO atstovai nedetalizuoja, kadangi Lietuvos iki pilnateisės NATO narystės nėra NATO bendros gynybos planuose.

${ }^{53}$ Office of the Assistant Secretary of Defense for International Security Affairs and the United States European Command Lithuanian Defense Assessment, 1998.

${ }^{54}$ Office of the Secretary of Defense. International Security and European Policy. Strategic Review of the Defense Plans and Military Capabilities of the Republic of Lithuania, 2001. 
Didèjantys JAV ịsipareigojimai mūsų regione atspindi gaunamą naudą ir numatomus kaštus, kylančius iš galimų ịsipareigojimų Lietuvai ir kitoms regiono valstybėms. Šiuos numatomus kaštus galima padalyti ị tris grupes:

- Politiniai - Rusijos reakcija į NATO plètrą ir JAV įsipareigojimus Baltijos šalims.

- Kariniai - sugebejjimas demonstruoti karinị pasiruošimą apginti Baltijos šalis.

- Finansiniai - pertvarkymai Baltijos šalyse dèl vykdomos integracijos į NATO.

Rusijos posūkis į Europą ir stiprejjanti JAV-Rusijos partnerystė mažina politinius JAV įsipareigojimų kaštus. Ne paslaptis, kad Lietuvos, Latvijos ir Estijos nesėkmė pirmajame NATO plètros etape buvo numanomų didelių politinių kaštų pasekmè. JAV vyraujant „Russia first“(angl.) politikai buvo baiminamasi, kad Baltijos šalių pakvietimas suduos didžiulį smūgi Rusijos demokratẻjimo procesui, grą̌žns šalį i autoritarizmą ar netgi prives prie naujos konfrontacijos tarp buvusių Šaltojo karo priešininku.

Panaši argumentacija dažnai buvo girdima ir prieš antrają NATO plètros bangą, nors jos stiprumas buvo smarkiai sumažèjęs. Visų pirma pirmoji plètros banga nepablogino JAV santykių su Rusija, antra, Baltijos šalių didžiulis progresas tiek ekonominèje, tiek karinèje srityje išmušè priešininkams argumentą apie Baltijos šalių nepasiruošimą narystei.

Rusijos pozicija taip pat pradèjo keistis. Dar prieš $2001 \mathrm{~m}$. rugsèjo $11 \mathrm{~d}$. įvykius Rusijos prezidentas viešèdamas Suomijoje $2001 \mathrm{~m}$. rugsëjo 3 d. pareiškè, kad jei Baltijos valstybès nori jungtis prie NATO, tai yra ju pasirinkimas, nors jis nemato šiam reikalui objektyvių priežasčių ${ }^{55}$. Pasikeitusi Rusijos retorika bei strateginé partnerystė su JAV, mažina amerikiečiu buvimo Baltijos regione politinių kaštų problemą ir daro ji labiau priimtiną JAV politikams.

Nors būsima NATO narystė yra puikus atgrasinamasis faktorius, tačiau jau dabar L. Wallino nuomone, ,kandidatès statusas sustiprina viltis sulaukti paramos agresijos atveju. Visi partneriai turi teisę reikalauti konsultacijų pagal Partnerystès sutarties 10 str. Faktiškai tai reiškia, kad agresorius patirtų didžiulę ekonominę ir politinę žalą ${ }^{a 56} .2004 \mathrm{~m}$. taps ES narèmis. Tai konflikto tarp Baltijos šaliu ir Rusijos atveju dar labiau padidintų jẻgos naudojimo politinius ir kitus kaštus. ES negalètų ramiai reaguoti į vienos šalies užpuolimą, žinodama, kad tai gali nulemti jos pačios ateitį. Blogiausio scenarijaus atveju - jei Rusijoje atgimsta revanšistinès nuotaikos, Baltijos šalių narystė NATO sumažintų atvirų grasinimų tikimybę. Tai reiškia, kad Baltijos valstybių narystė NATO (ypač su ES naryste) didina saugumą visame regione.

Detalesnè teoriškai numanomos konfliktinės situacijos studija paskelbta JAV Užsienio politikos analizės institute. Studijos „Strategic and Operational Implications of NATO Enlargement in the Baltic Region "išvadose rašoma, kad nepaisant visu politinių pasikeitimų ,ilgą laiką Rusija turi būti nagrinëjama kaip pagrindiné grésmé Baltijos regiono saugumui. Blogiausiu atveju, būtų vykdoma tokia operacija, kaip pavyzdžiui, Persijos įlankoje ir naudojami panašǔs pajègumai. Tai apimtų strategini pervežimą, greitą reagavimą bei specialiųu pajėgų dislokavimą, galimybę pradinėse

\footnotetext{
${ }^{55}$ Gorenburg (note 41), 27.
}

${ }^{56}$ Wallin (note 46 ). 
konflikto stadijose smogti smūgius oras-žemè, vykdyti operacijas prieš Rusijos povandeninius laivus“" 57 .

Autorių nuomone, JAV tektų pagrindinė našta ginant Baltijos šalis, nes ji užtikrinantų dominavimą ore bei dislokuotų specialiąsias pajėgas. Konflikto atveju JAV sugebėtų užtikrinti tokią paramą Baltijos šalims, tačiau problemų galètų iškilti tokiu atveju, jei JAV tuo metu dalyvautų kitame konflikte, pavyzdžiui, Persijos įlankoje, Šiaurès Rytų Azijoje ar Aljanso pietiniame flange.

Studijos autorių nuomone, jei Rusija konflikto metu pasitelktų tik ịprastinę ginkluotę, tai apginti Baltijos šalis nebūtų ypatingai sunku. Tačiau, „mūsų vertinimu, Baltijos valstybèms priešiškai nusiteikęs režimas puolimo metu greičiausiai neapsiribos tik ịprastinėmis priemonėmis. Todèl tiek sajungininkų, tiek Baltijos gynybos planuotojai neturètų atmesti varianto, jog Rusija nenaudos masinio naikinimo ginklo tik todèl, kad tai pažeistų tarptautinès teisės normas ar vestų prie platesnio konflikto “58 . Tokio konflikto tikimybė yra labai maža, todèl Amerikai Lietuvos ir kitų Baltijos valstybių priëmimo nauda yra daug didesne už galimus kaštus, net jei išsipildytų pačios blogiausios prognozès, - tokią išvadą daro studijos autoriai.

Apie Lietuvos gynybos galimybes nèra plačiai diskutuojama JAV oficialiuose ir akademiniuose sluoksniuose, šia tema nėra paskelbta jokių viešų publikacijų. Vis dèlto neoficialių diskusijų metu dažniausiai prieinama prie išvados, kad Lietuva agresijos atveju gali būti ginama keliai būdais. Pirma, svarstomas lenkiškas variantas, kurio atveju ginamasi naudojant didelius ịprastinès ginkluotès kiekius (tankus, artileriją, šarvuotas pėstininkų mašinas, puolamuosius sraigtasparnius, naikintuvus). Taip ginantis norima atremti priešininko ataką kovos lauke. Antra, ginantis naudojant „technologinį“ modeli, kai NATO parama ateina iš JAV, daugiausia tolimojo nuotolio pajègu pagalba (smūgiai vykdomi panaudojant tolimo nuotolio raketas, strateginius bombonešius). Mažai pasikliaujama ịprastine ginkluote ir pastiprinimais iš Europos. Trečias yra mišrus variantas. Šiuo atveju remiamasi tiek ịprastinèmis pajègomis, tiek iš tolumos vykdomais smūgiais. Paskutinis ir tik teorijoje egzistuojantis modelis yra atgrasinimas kerštu (angl. deterrence by retaliation). Šiuo atveju būtų naudojami ilgojo nuotolio smūgiai, bet pasirenkama ne kariniai, o civiliniai ir ekonominiai taikiniai. Greičiausiai būtų naudojami masinio naikinimo ginklai.

Šios skirtingos opcijos įvairiai palaikomos tiek JAV, tiek tarp jos sajungininkų, tiek tarp naujųjų NATO narių. Visų pirma akivaizdu, kad Šaltojo karo laikų abipusio sunaikinimo koncepcija grịstas paskutinis variantas ras mažiausia šalininkų tiek JAV, tiek Europoje, tiek Baltijos šalyse. JAV lengviausia būtų pažadèti technologinị modelị, kuris finansiškai būtų pats pigiausias ir remiasi jau dabar turimais JAV pajėgumais. Toks variantas nesusilauktų Baltijos šalių paramos, kadangi tuo atveju JAV lieka tik politiškai įsipareigojusi ginti jų nepriklausomybę ir konflikto metu potencialus agresorius gali suabejoti JAV įsipareigojimais ginti Baltijos šalis.

NATO Europos valstybès aiškiai pritartų tradiciškam lenkiškajam variantui. Tai reikalautų iš Baltijos valstybių kurti dideles pajègas, galinčias vykdyti teritorinès gynybos veiksmus, tačiau vargiai ar galètų prisidèti prie būsimų, toli nuo regiono vykdomų aljanso operacijų. Atsižvelgiant ị tai, kad NATO juda link mažų, mobilių ir greitai dislokuojamų pajègų, toks variantas yra sunkiai ịmanomas.

\footnotetext{
${ }^{57}$ Institute for Foreign Policy Analysis (note 37), 3.
}

${ }^{58}$ Ibidem. 
Greičiausiai Baltijos šalių gynybai, kaip kompromisas tarp Baltijos šalių poreikių ir sajungininkių galimybių, bus pasirinktas mišrus variantas. Jis reikš, kad konflikto atveju įvairaus pobūdžio pastiprinimai ateis tiek iš kaimynių, tiek iš JAV. Mišrus variantas garantuoja, kad atgrasinimas bus paremtas tiek karo neišvengiamumo, tiek keršto elementu. Baltijos valstybẻms jis reiškia, kad bus fiziškas juntamas JAV buvimas regione, ir tai smarkiai padidins atgrasinimo efektyvumą. Šiuo atveju Lietuva, kaip ir kitos Baltijos valstybès, yra suinteresuotos ne tik amerikiečių politiniais ịsipareigojimais, bet jų kariniu buvimu regione, galbūt net pastovia pajëgų dislokacija.

Papildomi NATO plètros kaštai yra susiję su Rusijos siekiu minimizuoti JAV įtaką mūsų regione. Visų pirma Rusija siekia apriboti JAV buvimą regione. Tai reiškia, kad naujoms NATO narems bus taikomi tam tikri apribojimai - nedislokuoti branduolinio ginklo ar nekurti karinių bazių. Antra, Europoje egzistuojantys ginklų kontrolès režimai bus išplečiami ị Baltijos šalis. Dar $1993 \mathrm{~m}$. Lietuva prisijungè prie Vienos dokumento, kuriuo ịsipareigojo teikti informaciją apie pagrindines karines pratybas bei turimą ginkluotę. $1999 \mathrm{~m}$. Lietuva paskelbè norą prisijungti prie İprastinès ginkluotės Europoje sutarties, kuris reglamentuoja ịprastinès ginkluotės kiekị regione. 2002 m. Lietuva prisijungè prie Atvirojo dangaus sutarties, leidžiančios kitoms valstybèms vykdyti žvalgomuosius skrydžius virš Lietuvos teritorijos.

Tokios priemonès reiškia, kad JAV negalès naudoti labai efektyvių priemonių garantuoti patikimą atgrasinimą, pavyzdžiui, dislokuoti branduolinio ginklą ar steigti karines bazes. Greičiausiai JAV ir sajungininkai bus pasiryžę taip elgtis dèl politinių priežasčių - amerikiečių buvimo apribojimas ir Baltijos valstybių prisijungimas prie ginklų kontrolès režimo suteikia Rusijai garantiją, kad, krizès tarp NATO ir Rusijos atveju, Baltijos šalyse nebus sukauptas karinis potencialas, grasinantis Rusijos saugumui. Tai politiniai kaštai, kurie yra neišvengiama plètros proceso dalis.

Nepriklausomai nuo pasirinko Baltijos šalių gynybos modelio finansiniai JAV įsivèlimo kaštai bus minimalūs, nors 1999 m. priimtų naujų narių integracija pasirodè sunkesnè nei buvo spejjama anksčiau. L. Wallino nuomone, „,nepakankamos anglụ kalbos žinios, lèta pažanga pertvarkant karines pajègas, resursų, reikalingų pajėgų modernizacijai, trūkumas, pasenusios operacinès koncepcijos - šie integracijos sunkumai mažina karinę naujų NATO šalių vertę aljansui. Tačiau Baltijos šalys atneša daug mažiau problemų i aljansą negu pirmosios bangos kandidatės. Lietuvos, Latvijos ir Estijos mažos, bet pakankamai modernios pajègos reikalauja gerokai mažiau pertvarkymų, kad galètų veikti kartu su amerikiečiais, nei tai buvo su ankstesnių kandidatų pajëgomis ${ }^{\text {"59 }}$.

Kaip rašo A. Wilkas $2002 \mathrm{~m}$. paskelbtame Rytų studijų centro raporte „Naujos NATO nauji nariai“ Baltijos šalys neturès didelių problemų integruojantis į NATO, palyginus su Čekija, Lenkija ar Vengrija 1999 metais. „Baltijos šalių kariuomenės buvo kuriamos nuo nulio devintojo dešimtmečio pradžioje, todèl jos neturi dideliu problemų priartėti prie NATO standartų. Didelis resursų, skiriamų modernizacijai, padidėjimas taip pat prisideda prie adaptacijos palengvinimo. Prisijungusios prie NATO, Baltijos šalys jau turès parengtas kariuomenes, prisitaikiusias prie NATO standartu “60.

\footnotetext{
${ }^{59}$ Wallin (note 46).

${ }^{60}$ Wilk A. The new members of the new NATO, Centre for Eastern Studies, Warsaw, http:// www.osw.waw.pl/en/epub/eRap2002/ecz_01.htm
} 
Mažos ir mobilios pajėgos, be abejonès, yra didelis pliusas NATO planuotojų akyse. Iš kitos pusės, CNA raporte pažymima, kad „dèl savo mažo dydžio ir ribotu resursų Baltijos šalys negali būti svarbūs karinių pajëgų tiekẻjai NATO šalių operacijoms. Jų karinès oro pajėgos daugiausia skirtos oro erdvės stebejjimui. Karinės jūrų pajègos vykdo tik išminavimo darbus. Sausumos pajègos gali NATO pasiūlyti ne daugiau kaip po vieną batalioną, sugebantį dalyvauti 5 str. NATO operacijose “61 ${ }^{\text {. Bet }}$ Lietuva, Latvija ir Estija gali pasiūlyti kai kurių NATO valstybėms svarbių specifinių pajègumų. CNA nuomone, ,svarbiausia yra BALTNET (Baltijos oro erdvès stebëjimo sistemos) prijungimas prie NATO stebejjimo sistemos. Po prijungimo NATO turès daugiau informacijos apie oro erdvę virš Baltijos jūros ir Šiaurès Vakarinès Rusijos dalies"62.

JAV Užsienio politikos analizès instituto studijoje „Strategic and Operational Implications of NATO Enlargement in the Baltic Region" pabrèžiama, kad yra dar vienas papildomas JAV didelę reikšmę turintis BALTNET integracijos aspektas „Baltijos šalys sudaro vieningą geostrateginę erdvę, kuri turi ypatingą reikšmę priešlèktuvinès ir priešraketinès gynybos sistemų integravimui bei defence-in-depth šiaurinių aljanso teritorijų gynybai ${ }^{63} .2002 \mathrm{~m}$. Baltijos šalys paskelbè, kad perka naujus radarus, kurie ateityje taip pat bus integruoti į BALTNET sistemą. Lietuva planuoja isigyti du vidutinio nuotolio, o Latvija ir Estija po vieną tolimojo nuotolio radarus. Šie planai sukèlè neigiamą Rusijos reakciją, kuri tvirtina, kad šie radarai bus naudojami renkant žvalgybinę informaciją bei gali būti pajungti ị JAV kuriamą priešraketinès gynybos sistemą.

Mažos, bet pakankamai modernios Baltijos valstybių pajėgos reiškia mažus jų integracijos finansinius kaštus tiek pačioms Baltijos šalims, tiek NATO valstybėms. Kaip rašoma JAV Užsienio politikos analizès instituto Baltojoje knygoje „Strategic and Operational Implications of NATO Enlargement in the Baltic Region", mažas šiu valstybių dydis reiškia, kad JAV nereikès pridèti daug resursų, norint garantuoti šalių saugumą. Ypač dabar, kai karinės agresijos tikimybė yra maža, JAV poreikis investuoti i š šias šalis yra gana mažas, o gaunama nauda atperka numatomus kaštus ${ }^{64}$. Tarptautinio valiutos fondo $2002 \mathrm{~m}$. atliktoje studijoje „The Baltics: Medium - Term Fiscal Issues Related to EU and NATO accesion", sakoma, kad visos Baltijos šalys sugebės atlaikyti su numatoma NATO ir ES naryste susijusius kaštus. „Su ES acquis susijusios išlaidos bus gana didelès - vien patenkinti aplinkos apsaugos reikalavimus turès būti skiriama apie 1 procentą BVP. Jau dabar, siekdamos narystès NATO, Baltijos šalys gynybai išlaidas padidino iki 2 procentų“65. Vis dèlto „dèl numatomo ekonominio augimo ir griežtos monetarines politikos, Baltijos šalys yra gerai pasiruošusios sutikti su ES ir NATO naryste susijusius fiskalinius iššǔkius".

Siekdama dar geriau paruošti Lietuvą narystei NATO, JAV skiria konkrečią paramą Lietuvos karinėms reformoms vykdyti. Pagal Tarptautinę karių mokymo ir švietimo programą (IMET), kuri Lietuvoje pradejo veikti 1992 metais, remiamos

\footnotetext{
${ }^{61}$ Gorenburg (note 41), 11

${ }^{62}$ Ibidem, 2

${ }^{63}$ Institute for Foreign Policy Analysis (note 37), 4.

${ }^{64}$ Ibidem, 1.

${ }^{65}$ International Monetary Fund The Baltics: Medium -Term Fiscal Issues Related to EU and NATO accession, 2002, 3-4.
} 
kariškių studijos karinėse mokslo institucijose. 1995 metais buvo skirta 200 tūkst. dol., 1996 m. - 498 tūkst. dol., 1997 - 520 tūkst. dol., 1998 m. - 650 tūkst. dol., 1999 m. -727 tūkst. dol., 2000 m. -760 tūkst. dol., 2001 m. -800 tūkst. dol. ${ }^{66}$

Svarbi JAV paramos dalis yra Foreign Military Finance (FMF) lèšos. 1996 metais Lietuvai pagal šia programą skirta $1,25 \mathrm{mln}$. dolerių (įsigytos taktinio ryšio priemonès). $1997 \mathrm{~m}$. už $1,5 \mathrm{mln}$. dol. buvo modernizuojamos taktinio ryšio priemonès, 1998 m. už 5,7 mln. dol. - ịsigyta įranga Regioniniam oro erdvès stebejjimo centrui bei Kartografijos centrui, 1999 m. už 4,7 mln. dol. Kartografijos centrui, ryšio priemonès bendram Lietuvos-Lenkijos balionui LITPOLBAT, $2000 \mathrm{~m}$. už 4,4 mln. dol. - ịranga Regioniniam oro erdvès stebejjimo centrui, ryšio priemonès, $2001 \mathrm{~m}$. už $6,5 \mathrm{mln}$. dol. planuojama įsigyti prieštankines sistemas, toliau modernizuoti ryšio priemones ${ }^{67}$.

Apibendrindami galime daryti išvadą, kad už politinę paramą ir saugumo garantijas, JAV turi patikimus ir proamerikietiškai nusiteikusius sajungininkus. Šie turi valią ir pajègumus prisidèti prie JAV politikos tikslų Europoje igyvendinimo. Baltijos šalys negali pretenduoti į tai, kad amerikiečiai jų vardan aukotų savo globalinius interesus ar mestų didžiulius resursus, kaip tai daroma vykdant politiką Irako ar Izraelio atžvilgiu. Tačiau pastaruoju metu, kai smarkiai sumažèjo JAV ịsitraukimo kaštai mūsų regione ir kai Baltijos šalys igauna didesnę reikšmę bendraeuropinejje arenoje, JAV ir Baltijos valstybių bendradarbiavimas pasiekè kokybiškai naują lygị.

\section{Būsimos bendradarbiavimo kryptys}

Lietuva, būdama besivienijančios Europos dalimi bei priklausydama tiek Šiaurès Europos, tiek Vidurio ir Rytų Europos geostrateginiams regionams, yra JAV specifinès politikos, nukreiptos būtent į šiuos regionus, dalis. Tačiau dẻl savo geopolitinès padèties specifikos - t.y. būdama proamerikietiško VR ir Šiaurès Europos šalių bloko viduryje bei turẻdama siena su Baltarusija ir Kaliningradu, Lietuva gali turèti savarankišką vaidmenį santykiuose su Europos valstybėmis ir JAV.

Visų pirma Lietuva turi didelę reikšmę, igyvendinant Vakarų valstybių politiką Baltarusijos atžvilgiu. Izoliavus Baltarusijos režimą, Lietuva ir Lenkija turi galimybę kalbėti tiek su Baltarusijos pozicija, tiek su opozicija bei skatinti reformas šioje šalyje. Lietuvos vaidmuo dar labiau padidès, kai autoritarinis režimas Baltarusijoje pasikeis.

Antra, Lietuva yra svarbi kaip Vakarų valstybių politikos integruoti Rusiją i Europos struktūras dalis. Lietuva, kaip didžiausias investuotojas ị Kaliningrado sritị, gali padèti pertvarkyti šią Rusijos dalị į bendradarbiavimo modelị tarp NATO/ES valstybės ir šalies, stengiančiosios suartėti su šiomis organizacijomis.

Net be šių išskirtinių savybių Lietuva išlaikys regioninès valstybės statusą JAV strategijoje. Lietuvos bei jos kaimynių ir JAV svarbiausia bendradarbiavimo arena išliks Europos politika bei transatlantiniai santykiai. Šiuo požiūriu tiek Šiaurès Europos, tiek VR Europos valstybės yra suinteresuotos stiprinti amerikiečių įsitraukimą, kai sprendžiami Europos saugumo klausimai, išlaikyti ir adaptuoti NATO aljansą bei transformuoti Rusiją ị demokratinę rinkos ekonomikos valstybę. Regiono

${ }^{66}$ Oficiali Krašto apsaugos ministerijos informacija, pateike Tarptautinių ryšių departamentas.

${ }^{67}$ Ibidem. 
valstybės nenori suteikti ES karinị matmenị ar kurti regioninius saugumo užtikrinimo mechanizmus. Toks saugumo interesų sutapimas skatina aktyvesnį bendradarbiavimą ir JAV saugumo strategijoje didina regiono reikšmę.

Dabartiniu metu JAV siekia stabilizuoti VR ir Šiaurès Europos regioną, suteikiant jam saugumo garantijas ir paverčiant ji Amerikos interesų Europoje ir pasaulyje iggyvendinimo įrankiu. Ateityje, kai regione nusistovès ramybè, galima prognozuoti, kad JAV susidoméjimas Lietuva ir jos kaimynėmis po truputị mažès. Turẻdama gana apčiuopiamą naudą iš bendradarbiavimo ir išlaikydama įtaką regione JAV minimaliais kaštais sieks išlaikyti regiono status quo, t.y. bus juntamas amerikiečiu buvimas regione, bet be didelio aktyvumo, ir kas svarbu regiono šalims, - be didesnès JAV finansinès paramos. Tuo labiau, kad jei regione nebus didelių neramumų ar tarptautinių konfliktų, Lietuva, kaip ir kitos Baltijos valstybės, po truputi virs tyliu ir stabiliu Europos užkampiu, regionu, esančiu toli nuo globalinių ir regioninių konfliktų zonų. JAV greičiausiai nuspręs, kad problemos šioje regiono dalyje jau išspręstos, todél jos interesas ir aktyvumas regione turètų mažèti.

Noredama išlaikyti JAV susidomėjimą, Lietuva privalo atrasti sritis, kur abiejų šalių interesai sutampa bei pasiūlyti JAV savo privalumus, kurie būtų naudingi JAV, siekiant globalinių ir regioninių tikslų. CSIS ir TSPMI VU rengtoje studijoje pažymima, kad „Lietuva gali stiprinti Amerikos interesus Europoje veikdama kaip patikima JAV sajungininke aljanso viduje ir paremdama JAV saugumo, prekybos ir verslo interesus. Lietuva turi tiek diplomatinių, tiek ekonominių, tiek karinių resursų tai įgyvendinti“ ${ }^{\text {“68 }}$. Lietuva, kaip ir kitos regiono šalys, turi rasti nišą, specializacijos sritis, kur jos savo veikla gali prisidèti prie JAV ar kitų Europos valstybių pastangų kitose pasaulio dalyse. Tai gali būti ekonominiai, kariniai, kultūriniai resursai, kurie JAV požiūriu būtų vertingi, iggyvendinant JAV politiką Europoje ir už jos ribų.

Tiesiausias kelias sukurti tokius pajėgumus yra regioninis bendradarbiavimas. VR ir Šiaurès Europa yra mažų valstybių regionas. Net ir tokios valstybės kaip Švedija ar Lenkija yra per mažos, kad pačios savarankiškai vaidintų svarbų vaidmenį globalinèje JAV strategijoje. Lietuva gali sustiprinti JAV interesus Europoje, veikdama kaip patikimas JAV parneris. Dẻl savo limituotų išteklių, Lietuva, kaip ir kitos VR ir Šiaurès Europos regiono valstybės, yra JAV force multiplyer, o ne savarankiškos veikèjos.

Amerikiečiu supratimu, tik veikdamos kartu ir sutelkdamos turimas pajègas, regiono valstybès gali kartu stiprinti stabilumą regione. JAV visą laiką palaikè regioninio bendradarbiavimo formas, tokias kaip Šiaurès šalių taryba, BALTSEA forumas, V 10 grupė, Vidurio Europos iniciatyva, nors prieštaravo, kad jos igautų konkretesnę formą ar vestų i saugumo regionalizavimą. Todèl, JAV požiūriu, vertingiausia yra kolektyvinès pastangos, igyvendinant tam tikrus projektus ar idejas. Galimi įvairūs mechanizmai, leidžiantys Lietuvai turèti daugiau ar mažiau įtakos tam tikruose regionuose.

\begin{tabular}{llllll}
\hline & $\begin{array}{l}\text { Rusija } \\
\text { Kaliningradas }\end{array}$ & Baltarusija & Ukraina & $\begin{array}{l}\text { Viduriné } \\
\text { Azija }\end{array}$ & Antiterorizmas \\
& didelè & didelé & vidutiné & maža & vidutiné \\
Baltijos jūros šalys & vidutiné & vidutinè & maža & maža & maža \\
Baltijos šalys & vidutiné & maža & vidutiné & maža & vidutiné \\
Vilniaus grupé & vidutiné & maža & maža & maža & maža \\
pavieniui & & &
\end{tabular}

${ }^{68}$ Center for Strategic and International Studies (CSIS), Institute of International Relations and Political Science, Vilnius, (note 2), 60. 
Veikdamos kartu, šalys gali ne tik sėkmingiau pasiekti savo tikslus, bet ir užsitikrinti politinę ir finansinę JAV paramą bei sulaukti didesnio dẻmesio Vašingtone. Tuo tikslu iniciatyva turètų būti grindžiama bent keletu bendrų principų:

- iniciatyva turètų vesti ị konkrečių pajègumų sukūrimą;

- iniciatyva turètų apimti Rusiją, Ukrainą, ateityje galbūt Baltarusiją;

- JAV dalyvavimo kaštai turètų būti minimalūs;

- iniciatyvos rezultatas turètų prisidèti prie antiteroristinės kampanijos ar vertybių i kitus regionus plètros.

Jau dabar egzistuoja nemažai forumų, kurie iš dalies tenkina šiuos kriterijus. Tokiu pavyzdžiu galètų būti $5+3+1$ forumas, kur JAV, Šiaurès ir Baltijos šalys aptaria svarbiausius Baltijos jūros regiono saugumo klausimus. Šis forumas turètų ne tik išlikti, bet ir plèstis. Siame forume galima būtų galvoti ir apie konkrečiu karinių ir nekarinių projektų vykdymą.

Svarbiausias iššūkis, kuris ateityje laukia Lietuvos, bus suderinti JAV politikos principus su nacionaliniais prioritetais. Kaip ES būsimoji narè Lietuva jau dabar laikosi ES BUSP bendrų pozicijų, kurių rekomendacijos ne visada sutampa su JAV norais. Skirtinga valstybiu galia, interesai patys savaime nurodo, kad kai kurie Lietuvos ir JAV prioritetai neabejotinai skirsis. Lietuva dèl ribotų išteklių daugiausia dėmesio skirs savo regiono problemoms, vis didesnę reikšmę užims vidaus problemų, kurios susijusios su integracija į ES, sprendimas. JAV spręs globalinius terorizmo, masinio naikinimo ginklų plètros ar tarptautinės ekonominès sistemos stabilumo klausimus.

\begin{tabular}{|c|c|c|c|}
\hline Interesai & JAV & Lietuva & $\begin{array}{l}\text { Lietuvos reikšmé JAV } \\
\text { strategijoje }\end{array}$ \\
\hline Globaliniai & $\begin{array}{l}\text { dominavimo } \\
\text { išlaikymas, } \\
\text { antiterorizmas, masinio } \\
\text { naikinimo ginklo } \\
\text { plètra; }\end{array}$ & $\begin{array}{l}\text { neturi savarankiškos } \\
\text { darbotvarkès, nedidelis } \\
\text { prioritetas; }\end{array}$ & $\begin{array}{l}\text { Lietuva veikia kaip } \\
\text { JAV pastangu } \\
\text { palaikytoja; }\end{array}$ \\
\hline Europiniai & $\begin{array}{l}\text { fiksuoti Rusija, stiprinti } \\
\text { NATO, palaikyti galios } \\
\text { balansą Europoje, } \\
\text { nemilitarizuota ES; }\end{array}$ & $\begin{array}{l}\text { sutampa su JAV } \\
\text { prioritetais; }\end{array}$ & $\begin{array}{l}\text { Didelès } \\
\text { bendradarbiavimo } \\
\text { galimybės konstruojant } \\
\text { politiką Rusijos } \\
\text { atžvilgiu, derinant } \\
\text { prioritetus ES viduje; }\end{array}$ \\
\hline Regioniniai & $\begin{array}{l}\text { nedidelis prioritetas, } \\
\text { apimantis tokius } \\
\text { bendrus principus, kaip } \\
\text { demokratinių vertybių } \\
\text { plètra. }\end{array}$ & $\begin{array}{l}\text { Baltarusijos } \\
\text { demokratizacija, } \\
\text { Kaliningrado } \\
\text { demilitarizacija. }\end{array}$ & $\begin{array}{l}\text { Lietuva stengiasi } \\
\text { itraukti JAV ¡ savo } \\
\text { regiono problemų } \\
\text { sprendimą. }\end{array}$ \\
\hline
\end{tabular}

JAV Užsienio politikos analizès instituto studijoje Strategic and Operational Implications of NATO Enlargement in the Baltic Region, teigiama, kad JAV panaudojo savo politini kapitalą ir pavertė NATO narystės svajones realybe ${ }^{69}$. Dabar Baltijos šalys turi atsilyginti tuo pačiu. Autorių nuomone, tai jos gali padaryti trimis būdais:

${ }^{69}$ Institute for Foreign Policy Analysis (note 37), 5. 
- toliau rimtai stiprinti savo karinius pajègumus bei galimybę veikti kartu su aljansu. Sparti sajungininkų pastiprinimų prièmimo pajègumų plètra turètų būti prioritetas, taip pat nereikia pamiršti pajëgumų, kurie dalyvaus taikos palaikymo operacijose.

- toliau tęsti dialogą su Rusija. Narystė NATO suteikia daugiau pasitikẻjimo ir palengvina bendradarbiavimą su Rusija, todèl dabar Baltijos šalys turi tapti tiltu tarp Rusijos ir NATO.

- kaip NATO valstybės Baltijos šalys turi atsakingai elgtis aljanso viduje. Kiekviena Baltijos šalis turès svarų balsą debatuose dèl NATO ateities. Baltijos šalys turi prisidèti prie kolektyvinès gynybos, kaip pagrindinès NATO misijos, svarbos išlaikymo.

JAV ypač laukia partnerių ir sajungininkų pagalbos fronte prieš tokias grèsmes, kaip ekonominis nestabilumas, ekstremizmas ar terorizmas. Demokratinių vertybių sklaida į kitus regionus amerikiečių akimis yra svarbiausia priemonė kovoje su šiomis grèsmèmis. Šiaurès šalys gana sẻmingai užèmè panašią nišą devintojo dešimtmečio pradžioje, kai skyrè didžiulį dėmesį ir padejjo demokratizuoti Baltijos šalis. Dabar tokios pastangos Rusijoje, Ukrainoje, Baltarusijoje, Kaukaze, Balkanuose, Vidurinèje ir Pietų Azijoje susilauktų dar didesnio JAV administracijos palaikymo.

Globaliniu lygiu taip pat svarbu bendradarbiauti su JAV sajungininkais ne tik Europoje, bet ir kitose pasaulio dalyse. JAV, be abejonès, teigiamai vertintų regiono valstybių platesnius saugumo ryšius su gyvybiškai svarbiomis, jos interesų požiūriu, šalimis Artimuosiuose Rytuose (Izraelis, Jordanija, Egiptas) bei Pietų Azijoje (Pakistanas, Afganistanas). Deja, šie regionai nèra prioritetiniai VR ir Šiaurès Europos valstybėms ir be didesnio dèmesio Vašingtone toks bendradarbiavimas papildomos naudos neatneštų.

JAV interesų požiūriu, ypač perspektyvios sritys, kuriose numatomas Rusijos ar Ukrainos dalyvavimas. Tokiais bendradarbiavimo pavyzdžiais galètų būti bendri projektai Kaliningrado srityje, apimantys ịvairias sritis: mokslą, aplinkos apsaugą, krizių valdymą. Ateityje tai galètu apimti ir karinius projektus arba kitokias iniciatyvas. Tokiu praktiniu bendradarbiavimo pavyzdžiu yra Švedijos ir Vokietijos Kylio iniciatyva, kurios tikslas yra skatinti kariniųjūrų pajëgų bendradarbiavimą Baltijos jūroje. Šioje iniciatyvoje tiek Rusija, tiek JAV, tiek kitos Baltijos jūros šalys sėkmingai vykdo išminavimo darbus Baltijos jūroje.

Panašūs prioritetai tarp JAV ir Lietuvos bei jos regiono valstybių turètų išlikti ir ateityje. JAV igyvendino savo viziją - ịtvirtino taikų ir demokratišką regioną, kuriame vyrauja jai draugiškos valstybės. Jas sieja bendri interesai, vertybės, noras plèsti demokratijos ir laisvos rinkos erdvę. Per pastarajį dešimtmetį JAV globalinëje strategijoje Lietuva igijo sajungininkès statusą, kuris duoda ne tik daug privilegiju, bet ir atsakomybę. Lietuvai suteiktos saugumo garantijos yra svarbiausia JAV intereso išraiška. Tai tuo pačiu ir skiriamoji linija, kuri dalina Lietuvos-JAV santykius ị dvi dalis - iki Prahos ir po jos.

Santykiai po Prahos turès visai kitą charakterị. Visų pirma daug didesnę reikšmę igaus NATO vidinių problemų svarstymas: jos adaptacija, vidinès reformos, out of area operacijos. Dalyvaudama NATO ir ES darbe Lietuvos turès formuoti savo poziciją globalinès politikos temomis, kaip santykiai su Iraku ar Šiaurès Korẻja, o tai iki šiol nebuvo Lietuvos užsienio politikos prioritetu. Platesnis problemų ratas turètų dar labiau suintensyvinti Lietuvos-JAV dialogą ir prisidèti prie konkrečių iniciatyvų igyvendinimo. 